\title{
Albumin and functionalized albumin nanoparticles: production strategies, characterization, and target indications
}

\author{
Abhishek Srivastava* $^{*}$, Anjali Prajapati ${ }^{\odot}$
}

\begin{abstract}
The inherent properties of albumin facilitate its effective use as a raw material to prepare a nanosized drug delivery vehicles. Because of the enhanced surface area, biocompatibility, and extended half-life of albumin nanoparticles, a number of drugs have been incorporated in albumin matrices in recent years. Furthermore, its ability to be conjugated to various receptor ligands makes albumin an ideal candidate for the increased delivery of drugs to specific sites. The present review provides an in-depth discussion of production strategies for the preparation of albumin and conjugated albumin nanoparticles and for the targeting of these formulations to specific organs and cancer cells. This review also provides insights into drug loading, release patterns, and cytotoxicity of various drug-loaded albumin nanoparticles.
\end{abstract}

Keywords: albumin; drug delivery systems; drug liberation; nanoparticles; neoplasms

Neoplasms, a disease category including malignant cancers, are recognized as a principle cause of mortality worldwide. The most common treatments include radiation therapy, chemotherapy, and surgery. Surgery is considered to be the first most successful treatment for various types of solid tumors. In radiation therapy, high-energy gamma radiation from various radioactive elements is used to kill cancer cells, shrink tumors, and arrest the division and growth of cancer cells [1]. Chemotherapy involves the administration of anticancer drugs in multiple cycles; normal tissues may also be adversely affected by chemotherapy. Renal and hepatic toxicity and lower availability of the drug at the site of action are the major disadvantages of chemotherapy. A biocompatible and target-specific drug delivery vehicle could address the major concerns for this mode of treatment.
The efficiency and specificity of drug action can be improved by using target-specific nanocarrier systems. These include quantum dots [2], dendrimers [3], magnetic nanoparticles [4-6], solid-lipid nanoparticles [7-9], ceramic nanoparticles [3], colloidal nanoliposomes [10], polymeric and functionalized polymeric nanoparticles [11, 12], metal and inorganic nanoparticles [13], phospholipid micelles [14], and polymeric micelles [15]. Over the past few decades, a number of drug delivery systems have been introduced to improve the treatment of various disorders and diseases. Albumin, in its various forms, provides broad opportunities in the area of targeted drug delivery $[16,17]$. Among the available colloidal drug carriers for the treatment of cancer, protein-based nanocarriers are promising because of their storage stability, relative lack of toxicity and antigenicity, biodegradability,

*Correspondence to: Abhishek Srivastava, Department of Chemistry, GLA University, Chaumuhan, Mathura, Uttar Pradesh 281406, India, e-mail: aabhichem@gla.ac.in

Department of Chemistry, GLA University, Mathura, Uttar Pradesh 281406, India

¿ Open Access. ๑ 2020 Srivastava and Prajapati, published by Sciendo. (c) BY-NC-ND This work is licensed under the Creative Commons Attribution NonCommercial-NoDerivatives 4.0 License. 
and ease of scale-up [18]. Its high solubility in water and ease of purification make albumin a classical candidate both for nanoparticle preparation and as a versatile drug carrier that can be easily delivered through injection [19]. The amine and carboxyl groups present in the albumin molecules can be utilized for the incorporation of drug and other molecules into the albumin nanoparticles via covalent bonding [19].

The present review is intended to specifically focus on an in-depth discussion about the production strategies for preparing albumin and conjugated albumin nanoparticles and provides insights into drug-loading and -release patterns, target indications, and cytotoxicity of various drug-loaded albumin nanoparticles.

\section{Search strategy}

A search was performed across electronic databases. Articles relevant to the production and applications of albumin nanoparticles published up to July 2020 were retrieved from Scopus, PubMed, and Google Scholar using the following keywords: "Albumin nanoparticles" or "Functionalized albumin nanoparticles" or "Surface modified albumin nanoparticles" or "Drug loaded albumin nanoparticles" and "Desolvation process" or "Thermal gelation" or "Emulsification process" or "Nab technology" or "Selfassembly" and "Targeted drug delivery systems".

\section{Albumin types}

\section{Human serum albumin}

Human serum albumin (HSA) functions as a carrier protein in the blood to bind and transport fatty acids [20], thyroid hormones [21], steroids [22], endogenous ligands, metabolites, and drugs [23], and plays a vital role to stabilize extracellular fluid volume [24]. HSA is the most abundant of all plasma proteins $(60 \%)$ and is a water-soluble globular protein present at $35-50 \mathrm{~g}$ protein/L of human serum. It has an average halflife of 19 days and helps to regulate the blood $\mathrm{pH}$ and maintain the colloidal osmotic blood pressure [25]. Serum albumin binds $\mathrm{Ni}(\mathrm{II}), \mathrm{Cu}(\mathrm{II}), \mathrm{Zn}(\mathrm{II})$, and $\mathrm{Ca}(\mathrm{II})$ and also functions as a transport vehicle for these metal ions in the blood [25]. Amino acids produced after degradation of albumin provide nutrition to surrounding tissues. It is a low-molecular-weight (66,500 Da) single-chain protein consisting of 585 amino acid residues [26].

The heart-shaped structure is composed of Domain I (residues 1-195), Domain II (residues 196-383), and Domain
III (residues 384-585), which are bound together via weak physical forces of attraction. HSA contains 35 cysteine residues, of which 34 form disulfide bridges and contribute to its high stability; the one free sulfhydryl group at position 34 (Cys-34), located on the protein surface, facilitates the covalent conjugation of drug and dimerization [27].

\section{Bovine serum albumin}

Bovine serum albumin (BSA) or Fraction $\mathrm{V}$, the major protein of bovine blood plasma, has a molecular weight of $66,463 \mathrm{Da}$ and an isoelectric point of 4.7. The precursor protein of BSA contains 607 amino acids along its full length. Upon secretion, an 18-residue signal protein is cleaved from the $N$-terminal of the precursor protein, resulting in a protein product containing 589 amino acid residues [28]. After cleavage of 6 amino acid residues, the mature BSA protein contains 583 amino acids. Because of its low cost, biodegradability, ease of purification, and favorable drug-ligand-binding and encapsulating properties, it has found wide applications in drug delivery and in the diagnosis of diseases such as malaria, tuberculosis, and acquired immunodeficiency syndrome (AIDS) [18]. The chemical composition, spatial structure, and biological properties of BSA are quite similar to those of HSA. Although the 2 proteins are very similar in their amino acid composition (76\%), BSA contains 2 tryptophan residues compared with1 residue in HSA.

\section{Ovalbumin}

Ovalbumin also known as egg albumin, the first protein isolated in pure form, is the major globular protein of avian egg white, with an isoelectric point of 4.8 . It belongs to the serpin family, but does not show any protease inhibitor activity. Ovalbumin is a glycoprotein with a molecular weight of 47,000 Da and is composed of 385 amino acid residues [29]. Individual ovalbumin molecules contain 6 cysteine residues, of which 2 are involved in internal disulfide linkage, while 4 are free as sulfhydryl groups. Ovalbumin has found widespread application in the food industry because of its ability to form foams and gel networks.

\section{Albumin nanoparticle preparation strategies}

The synthetic method adopted for the production of nanoparticles can use either a top-down or bottom-up approach. The top-down approach involves the breaking up of larger materials into nanoparticles through ball milling, etching, photolithography, or grinding. The particles produced are generally large, and the method is time consuming. 
The bottom-up approach refers to the fabrication of nanoparticles atom by atom, molecule by molecule, or cluster by cluster. The process proceeds through chemical reactions under controlled conditions in a liquid or gas phase, which results in nucleation and nanoparticle growth. The bottom-up process includes high-pressure homogenization, desolvation, coprecipitation, salting out, nanoprecipitation, solvent emulsification-diffusion technique, nanospray drying, selfassembly, thermal gelation, microfluidic technique, and nab technology [30]. The principal techniques adopted for the production of albumin and functionalized albumin nanoparticles involve desolvation, thermal gelation, emulsification, nab technology, self-assembly, and nanospray drying. A schematic representation of the different processes used for the preparation of albumin nanoparticles is shown in Figure 1.

\section{Drug loading, entrapment efficiency, and nanoparticle yield}

The drug-loading capacity of the nanoparticles and their entrapment efficiency can be calculated by determining the drug present in the supernatant using an ultraviolet (UV)-visible spectrophotometer or high-performance liquid chromatography (HPLC) system. Drug loading is the ratio of the amount of drug present in the drug-albumin nanoparticle to the total weight of the nanoparticles obtained [31, 32].

Drug-loading capacity $(\%)=$

Total weight of drug - Drug present in supernatant Total weight of nanoparticles $\times 100$

Drug entrapment/encapsulation efficiency can be calculated as the ratio of the drug present in the nanoparticles to the total weight of drug taken $[31,32]$.

Drug entrapment efficiency $(\%)=$

Total weight of drug-Drug present in supernatant Total weight of drug

Drug-albumin nanoparticle yield is the ratio of the weight of drug-albumin nanoparticles obtained at the completion of the process to the total weight of the albumin and drug used during nanoparticle formulation [32].

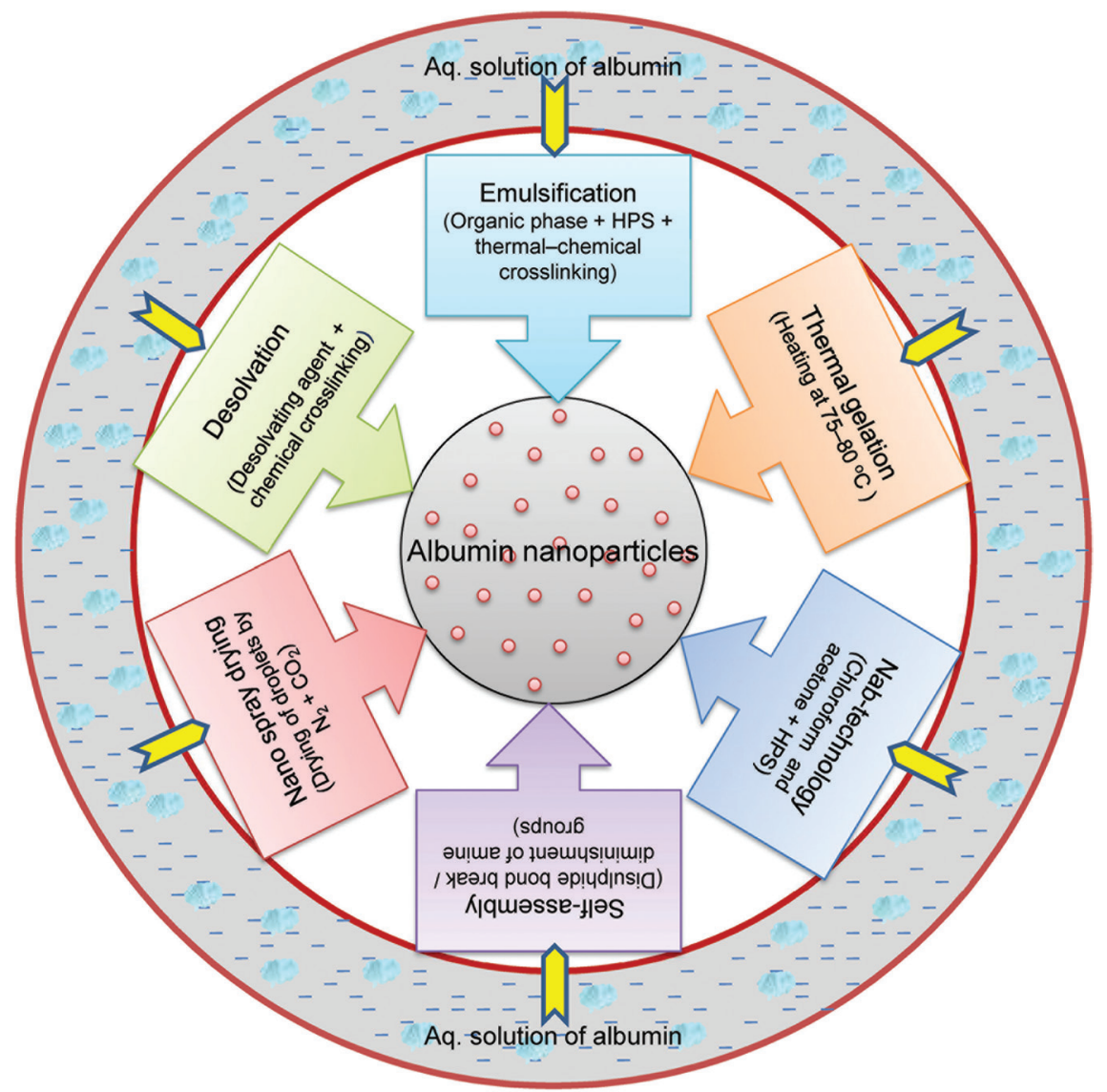

Figure 1. Various processes for the preparation of albumin nanoparticles. 
Nanoparticle yield $(\%)=$

Weight of drug-loaded albumin nanoparticles

Total weight of (albumin + drug)

Li et al. [31] calculated the nanoparticle yield by quantifying the nondesolvated albumin using a standard bicinchoninic acid protein assay as only the desolvated albumin will participate in the drug encapsulation process.

Nanoparticle yield $(\%)=$

Total weight of albumin - Weight of free albumin Total weight of albumin $\times 100$

\section{Drug release pattern and cytotoxic studies}

The release behavior of the drug from drug-loaded albumin nanoparticles can be evaluated in vitro by determining the amount of drug released from a fixed volume of samples withdrawn from the exterior of a dialysis bag at various intervals. In brief, a calculated amount of aqueous solution of drug-loaded albumin nanoparticles is sealed in a dialysis bag. The bag is then immersed in a known volume of phosphatebuffered saline (PBS) ( $\mathrm{pH} 7.4)$ incubated at $37{ }^{\circ} \mathrm{C}$ with stirring at $100 \mathrm{rpm}$. A small amount of sample is withdrawn at predefined time points from the exterior of the bag in the release medium, and the same amount of fresh PBS solution is added to maintain a fixed volume. Each withdrawn sample is centrifuged, and the amount of drug in the supernatant is determined by HPLC or fluorescence/UV-visible spectrophotometry. A plot of the cumulative drug release against time provides a better understanding of the release pattern [33]. Cell viability and cytotoxicity are generally assessed in vitro using 3-[4,5-dimethylthiazol-2-yl]-2,5diphenyltetrazolium bromide (MTT) reduction [33].

\section{Desolvation or coacervation method}

The desolvation process involves the continuous or intermittent dropwise addition of a desolvating agent (methanol, acetone, or ethanol) into an aqueous solution of albumin with constant stirring until turbidity appears, indicating the formation of nanoparticles [18]. Nanoparticles thus formed are not stable and could redissolve in water or may aggregate. Therefore, the nanoparticles formed are stabilized using a crosslinker (glutaraldehyde or $\mathrm{N}$-(3-dimethylaminopropyl)- $\mathrm{N}$ ethylcarbodiimide [EDC]) [34] (Figure 2). Glutaraldehyde hardens the nanoparticles by condensation cross-linking of the amino moieties present in the albumin side chain (Figure 3), while EDC stabilizes the nanoparticles by forming a peptide bond between the amino and carboxyl groups of amino acids. Stirring is continued for $6 \mathrm{~h}$ to ensure the cross-linking of all amino acid residues [35].

The process parameters for production of albumin nanoparticles using the desolvation process are represented in Table 1.

Langer et al. [18] reported a desolvation process for the preparation of HSA nanoparticles of a controllable diameter (150-250 nm) with narrow size distribution. To optimize the preparation process, various process parameters, viz., rate of ethanol addition, $\mathrm{pH}$ value, HSA concentration, and glutaraldehyde amount, were examined. Pump-controlled addition of ethanol had no considerable effect on particle size [18]. The results indicate that the $\mathrm{pH}$ of the HSA solution is the key parameter in effectively controlling the particle size,

\section{Desolvating agent}

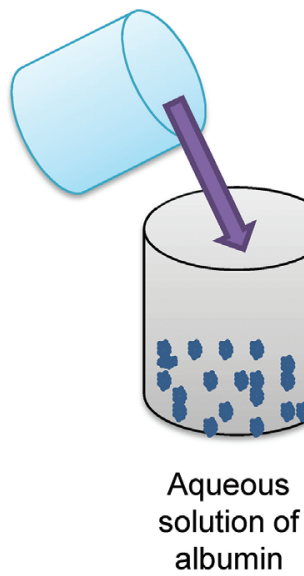

solution of albumin
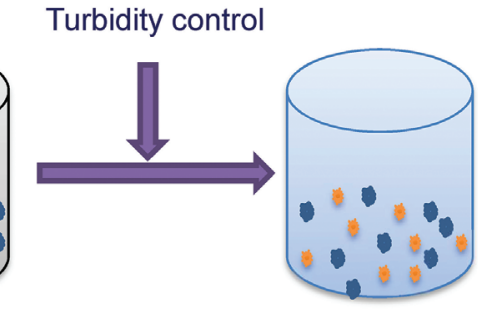

Albumin aggregates

\section{Crosslinker}

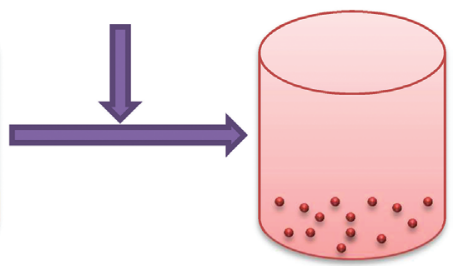

Albumin nanoparticles

Figure 2. Desolvation process for preparation of albumin nanoparticles. 


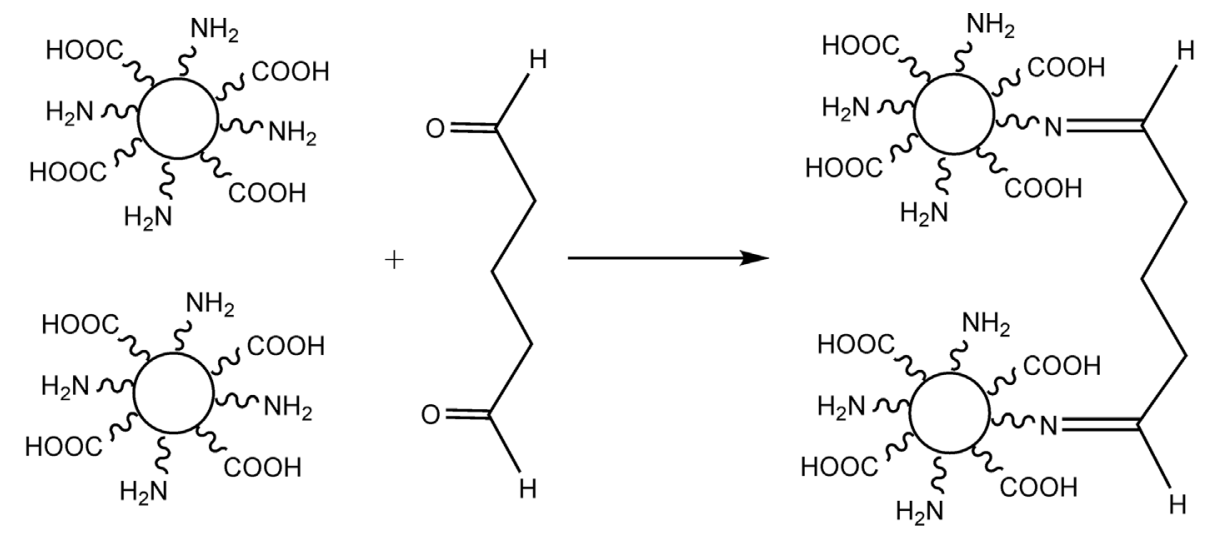

\section{Albumin nanoparticles Glutaraldehyde Crosslinked albumin nanoparticles}

Figure 3. Chemical cross-linking of albumin nanoparticles.

Table 1. Process parameters for production of albumin nanoparticles by desolvation

\begin{tabular}{|c|c|c|c|c|}
\hline Albumin used & Preparation conditions & $\begin{array}{l}\text { Particle diameter } \\
(\mathrm{nm}) \text {, approximate }\end{array}$ & Zeta potential & Reference \\
\hline HSA & $\begin{array}{l}\mathrm{HSA}: 100 \mathrm{mg} / \mathrm{mL} \text { in } 10 \mathrm{mM} \mathrm{NaCl}, \mathrm{pH}: 8.2 \text {; ethanol addition rate: } \\
1 \mathrm{~mL} / \mathrm{min} \text {; cross-linker: } 8 \% \text { glutaraldehyde; stirring rate: } 500 \mathrm{rpm}\end{array}$ & 150 & $-44 m V$ & [18] \\
\hline $\mathrm{BSA}+\mathrm{HSA}$ & $\begin{array}{l}\text { Protein: } 250 \mathrm{mg} / 4 \mathrm{~mL} \text {; stirring rate: 1,250 rpm; desolvating } \\
\text { agent: ethanol; cross-linker: } 5 \mathrm{mg} \text { EDC; stirring time: } 3 \mathrm{~h}\end{array}$ & 100 & $\begin{array}{l}\text { BSA: }-35 \mathrm{mV} \\
\text { HSA: }-29.6 \mathrm{mV}\end{array}$ & [35] \\
\hline BSA & $\begin{array}{l}\text { BSA: } 50 \mathrm{mg} / \mathrm{mL} \text { in } 10 \mathrm{mM} \mathrm{NaCl}, \mathrm{pH}: 7 \text {; cross-linker: } 8 \% \text { glutaral- } \\
\text { dehyde; desolvating agent: ethanol }\end{array}$ & 100 & - & [36] \\
\hline BSA & $\begin{array}{l}\mathrm{BSA}: 100 \mathrm{mg} \text { in } 10 \mathrm{mM} \mathrm{NaCl}, \mathrm{pH}: 7.0 \text {; ethanol addition rate: } \\
1 \mathrm{~mL} / \mathrm{min} \text {; cross-linker: } 8 \% \text { glutaraldehyde; stirring rate: } \\
500 \mathrm{rpm} \text {; stirring time: } 30 \mathrm{~min}\end{array}$ & $100-300$ & - & [37] \\
\hline BSA & $\begin{array}{l}\text { BSA: } 1 \% \text { solution, } \mathrm{pH}: 6.0 \text {; ethanol addition rate: } 1 \mathrm{~mL} / \mathrm{min} \text {; } \\
\text { cross-linker: glutaraldehyde; stirring rate: } 700 \mathrm{rpm}\end{array}$ & 100 & - & [38] \\
\hline BSA & $\begin{array}{l}\text { BSA: } 100 \text { mg/mL, desolvating agent: ethanol; stirring rate: } \\
500 \text { rpm; pH: 8.2; cross-linker: } 8 \% \text { glutaraldehyde }\end{array}$ & 139 & $-50 \mathrm{mV}$ & [39] \\
\hline Egg white & $\begin{array}{l}\text { Egg white: } 10 \% \text {, pH 7.0; desolvating agent: ethanol; stirring rate: } \\
550 \text { rpm; cross-linker: } 8 \% \text { glutaraldehyde }\end{array}$ & 100 & $-28 m V$ & [40] \\
\hline
\end{tabular}

BSA, bovine serum albumin; EDC, $N$-(3-dimethylaminopropyl)- $N$-ethylcarbodiimide; Egg white = crude ovalbumin; HSA, human serum albumin.

with higher $\mathrm{pH}$ leading to smaller nanoparticles. Washing the particles in an alkaline medium with differential centrifugation produces nanoparticles of smaller diameter with narrower size distributions [18]. Esfahlan et al. [35] used EDC as a crosslinker for the rapid production of albumin nanoparticles. They used a self-developed mechanism for the controlled addition of the desolvating agent. The result shows that nanoparticles of around $100 \mathrm{~nm}$ diameter and polydispersity $<0.2$ were obtained without using salt and buffer.

A major issue with protein nanoparticles is their size inconsistency and colloidal instability due to their high tendency to agglomerate. Galisteo-González and Molina-Bolívar [36] found that BSA nanoparticles dispersed in an aqueous phase were stable even after 2 months at $4{ }^{\circ} \mathrm{C}$, without the particle diameter and size distribution being affected. Colloidal nanoparticles can serve as a drug carrier system only if they are taken up by the cells. Cellular uptake studies of HSA nanoparticles with primary human blood-derived macrophages were performed by Langer et al. [18] using fluorescence-activated cell sorting analysis and confocal microscopic imaging. The results showed that at concentrations $>100 \mathrm{mg} / \mathrm{mL}$ of HSA, nearly all cells took up HSA nanoparticles. The trace amounts of the cross-linker and organic solvents (methanol or ethanol) used in the desolvation process exert toxic effects on the biological system.

\section{Strategies for drug loading}

The amine and carboxyl groups present in albumin can be used to incorporate drug and other molecules with albumin 

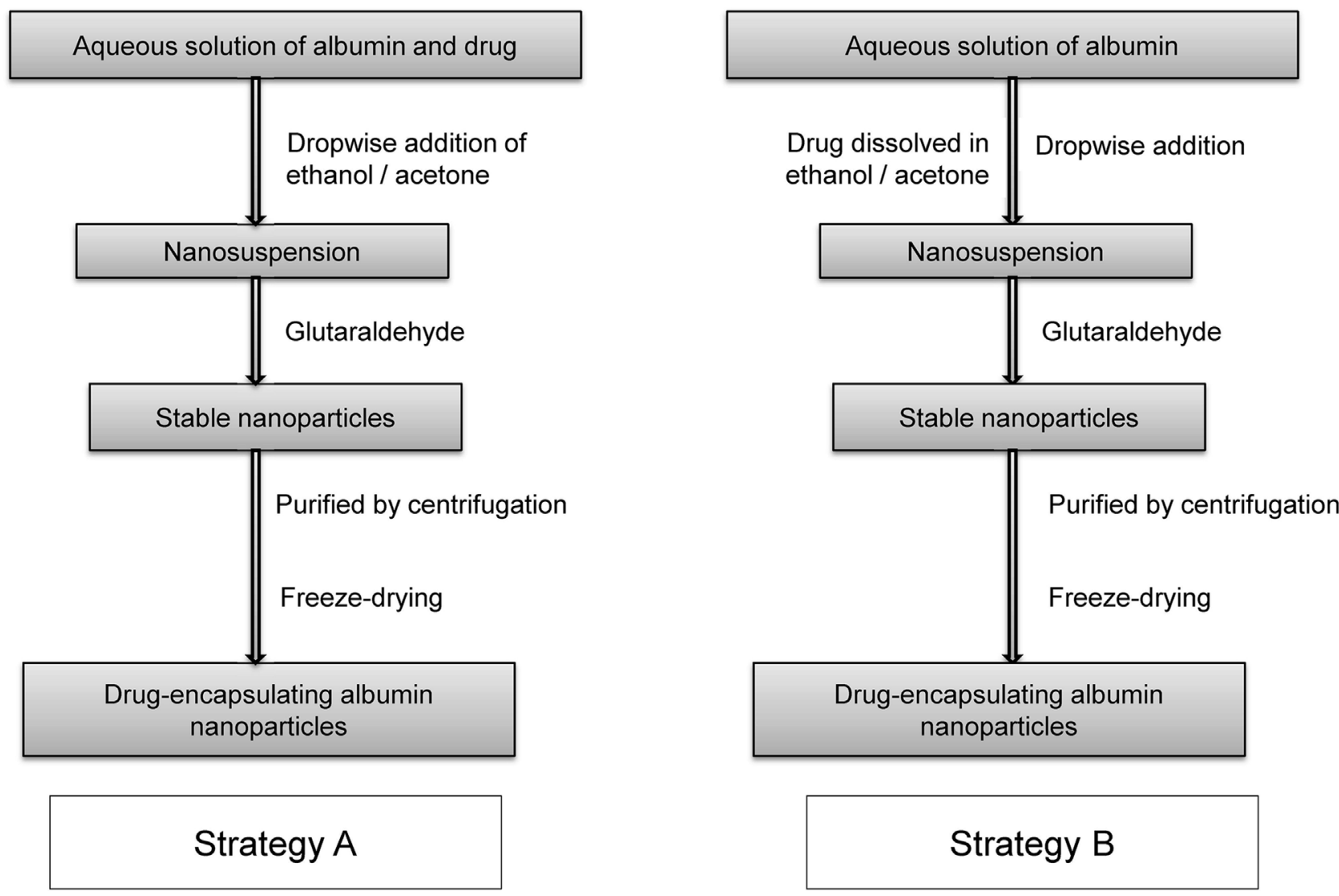

Figure 4. Preparation of drug-loaded albumin nanoparticles using desolvation process.

nanoparticles via covalent bonding. Depending on the solubility of the drug in water, two strategies are generally adopted to prepare drug-loaded albumin nanoparticles using the desolvation process (Figure 4). For water-soluble drugs, the drug is added to an aqueous solution of albumin at a fixed $\mathrm{pH}$, and the desolvating agent (ethanol/acetone) is added dropwise with constant stirring; the nanoparticles thus formed are stabilized through cross-linking with glutaraldehyde [31]. For water-insoluble drugs, the drug is dissolved in ethanol/ acetone, which is then added dropwise as a desolvating agent to an aqueous solution of albumin at fixed $\mathrm{pH}$. The nanoparticles thus obtained are stabilized using glutaraldehyde [32].

Albumin nanoparticles can be effectively used as carriers for the targeted delivery of bioactive molecules and anticancer drugs. There are numerous reports about the preparation of drugloaded albumin nanoparticles using the desolvation process [41, 42]. Dreis et al. [43] developed a standard protocol for the production of doxorubicin-loaded HSA nanoparticles. The size and stability of the nanoparticles varied with the $\mathrm{pH}$ value, amount of cross-linker, and concentration of doxorubicin used in the desolvation process. Nanoparticles of diameter 150-500 nm with a loading efficiency of $70 \%-95 \%$ were obtained at $20.0 \mathrm{mg} / \mathrm{mL}$ HSA and $1.0 \mathrm{mg} / \mathrm{mL}$ doxorubicin, with $100 \%$ cross-linking, without adjusting the $\mathrm{pH}$ (6.5) of the reaction medium. The nanosuspension was stable for up to 6 months at $4{ }^{\circ} \mathrm{C}$ with no change in particle size. The doxorubicin-loaded nanoparticles thus prepared showed enhanced inhibition of the proliferation of neuroblastoma cell lines, compared with the effect of doxorubicin solution [43]. Response surface methodology was used for process optimization and preparation of curcumin-loaded ovalbumin nanoparticles. Curcuminloaded ovalbumin nanoparticles showed enhanced solubility (34\%) and stability for curcumin. Nanoparticles of $232 \mathrm{~nm}$ with entrapment efficiency of 55\% and loading capacity of $4 \%$ were obtained [32]. Li et al. [31] used a desolvation process to prepare sodium ferulate (SF) entrapped in BSA nanoparticles (SF-BSA-NPs) with ethanol and glutaraldehyde as the desolvating agent and the cross-linker, respectively. The negatively charged 100 to $200 \mathrm{~nm}$ nanoparticles exhibited loading capacity of $16 \%$ and entrapment efficiency of about $80 \%$. The pattern of release from nanoparticles in vitro showed an initial burst effect, followed by a sustained release of SF. After administration of SF-BSA-NPs, there was a much higher distribution of the drug in the liver compared with that of free SF in solution [31]. The spherical BSA-entrapped ginsenoside Compound $\mathrm{K}(\mathrm{CK})$ (BSA-CK) nanoparticles are stable in 
biological buffer, whereas they degrade readily under acidic conditions. In vitro, these nanoparticles containing ginsenoside CK demonstrate enhanced solubility and therapeutic index toward an HT29 colon cancer cell line, an A546 lung cancer cell line, a HepG2 hepatocarcinoma cell line, and a HaCaT skin cancer cell line [44].

Salicylic acid (SA) undergoes $50 \%$ decomposition when administered orally to adults [33]. To increase the bioavailability of SA, BSA nanoparticles entrapping SA have been synthesized at various $\mathrm{pH}$ values and characterized by field emission scanning electron microscopy and transmission electron microscopy. The release of SA in vitro was studied through fluorescence in phosphate-buffered conditions. The results showed an instant release of SA with a progressive increase up to $120 \mathrm{~min}$; subsequently, the release rate of SA decreases and after $400 \mathrm{~min}$, it remains almost constant [33].

The increased surface area of the nanoscale particles makes them ideal candidates for surface functionalization and modification [45]. To improve the targeting efficiency of the carrier and the therapeutic index of the associated drug, it is desirable to incorporate target-specific ligands into nanoparticulate systems. The ligands have the specific ability to recognize and bind to the unique receptors present on particular cancer cells [46]. Because of the presence of carboxyl and amine groups on the surface of albumin, various surface modifications, enrichment, and functionalization of albumin nanoparticles are possible through covalent bonding between the desired ligands and functional groups. A number of receptors have been identified by researchers as being overexpressed on various types of cancer cells. Folic acid receptors are consistently overexpressed in a wide variety of human cancer cells (tumors of the kidney, lung, breast, cervix, ovary, and brain), with limited expression in healthy tissues [3].

Folic acid is stable over a wide range of $\mathrm{pH}$ values and temperatures, is nonimmunogenic and inexpensive, and has the specific ability to bind to folate receptors after conjugation with the drug-loaded albumin nanoparticles (Figure 5). After binding with receptors, folates are internalized into the cell via an endocytic pathway. A slight decrease in $\mathrm{pH}$ (to about 5) alters the conformation of receptors, resulting in the detachment of folate from the receptor and the release of the cytotoxic drug into the cell [3]. To overcome the poor water solubility and nonspecific targeting of bexarotene (BEX), Qi et al. [47] prepared folate-conjugated BEX-BSA nanoparticles using a desolvation process. The resultant nanoparticles had narrow size distribution, with particle diameter and surface charge of about $200 \mathrm{~nm}$ and $-33.64 \mathrm{mV}$, respectively. A549 and MCF-7 cancer cell lines show the excellent binding of folate to cancer cells in vitro, thereby increasing the potency and specificity of BEX, promoting apoptosis of tumor cells, and reducing the cytotoxicity of the drug to A549 cells [47].

Chen et al. [48] prepared folate-conjugated HSA nanoparticles by first activating folic acid using EDC and then conjugating it to HSA. Folate-conjugated HSA magnetic cisplatin nanoparticles were synthesized by mixing folate$\mathrm{HSA}, \mathrm{Fe}_{3} \mathrm{O}_{4}$ magnetic nanoparticles, and cisplatin at $\mathrm{pH} 9.0$ using ethanol as a desolvating agent, with subsequent crosslinking using glutaraldehyde. The resultant nanoparticles were centrifuged at 7,100 $\times g$, washed with water, and dried under vacuum. The cisplatin-loaded magnetic nanoparticles
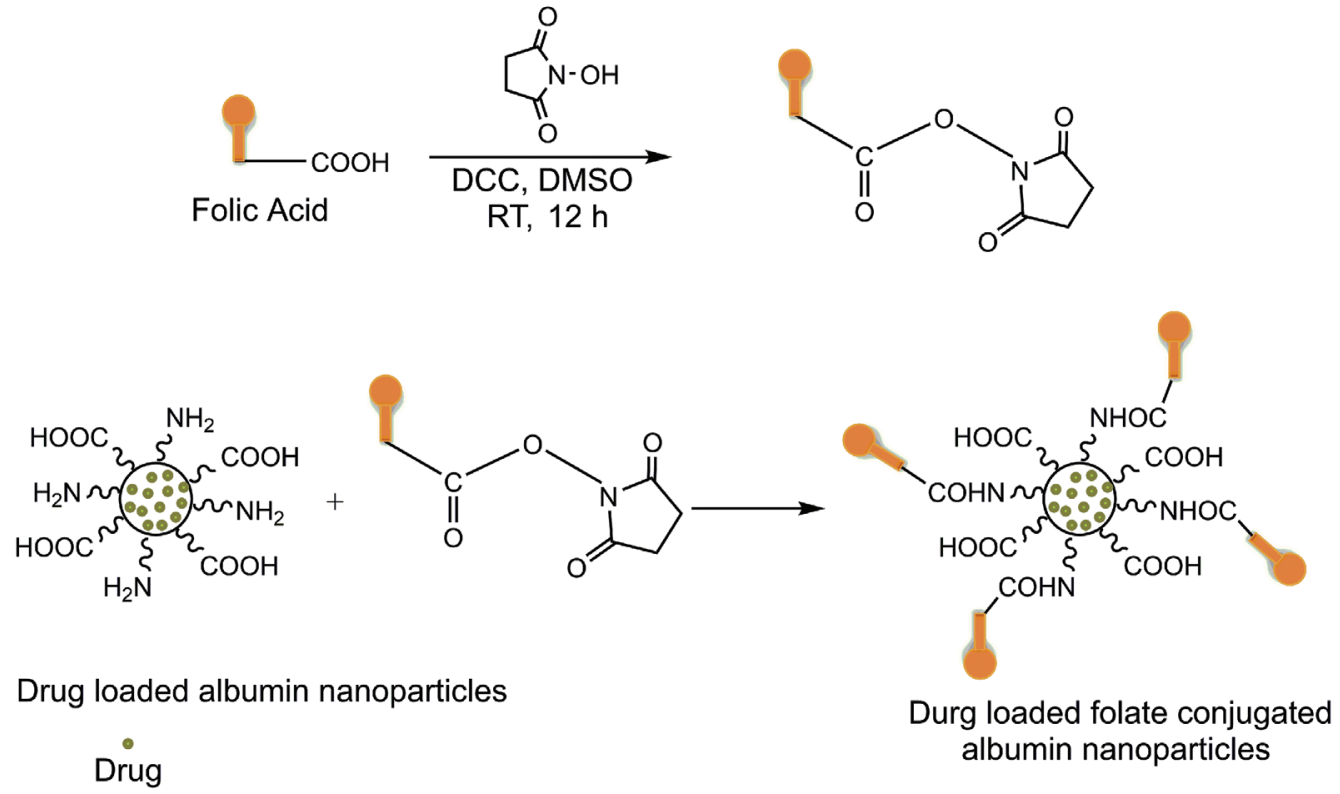

Figure 5. Preparation of drug-loaded folic acid-decorated albumin nanoparticles. 
of $79 \mathrm{~nm}$ diameter exhibited $15 \%$ loading capacity and $90 \%$ entrapment efficiency [48]. The drug release pattern of nanoparticles is sustained for $24 \mathrm{~h}$. Magnetic nanoparticles can be selectively concentrated on the targeted tumor sites by the application of a static magnetic field. Upon changing the magnitude of the field, the magnetic nanoparticles will absorb electromagnetic energy to raise the local temperature in the range of $42-46{ }^{\circ} \mathrm{C}$ to kill tumor cells. Thus, the magnetic drug-loaded folate-conjugated nanoparticles demonstrate a combination of target-specific chemotherapy and thermotherapy.

A desolvation process was adopted by Nosrati et al. [49] to prepare chrysin (CHA)-loaded BSA nanoparticles (CHA-BSA). To make them target specific, folic acid was conjugated to its surface via carbodiimide chemistry. The resultant spherical nanoparticles (CHA-BSA-FA) were of $97.5 \mathrm{~nm}$ diameter with zeta potential of $-11.0 \mathrm{mV}$. The release behavior of CHA-BSA-FA nanoparticles was studied in vitro over $168 \mathrm{~h}$ in phosphate-buffered conditions at $\mathrm{pH} 7.3$ and 5.8. There was an initial release of $20 \%$ drug in $10 \mathrm{~h}$ at both $\mathrm{pH}$. By contrast, at $\mathrm{pH} 5.8$, there was $57 \%$ release, but only $35 \%$ sustained release was observed at $\mathrm{pH}$ 7.3 in $96 \mathrm{~h}$ and a plateau level was achieved after $120 \mathrm{~h}$. An MTT cytotoxicity assay showed that the folate-conjugated nanocarrier exhibited enhanced inhibition of MCF-7 cancer cells compared with CHA-BSA nanoparticles and plain CHA solution [49].

Due to the negative charge on the surface of albumin, low loading of negatively charged drugs is expected during drug loading of albumin nanoparticles [50]. Mohammad-Beigi et al. [50] prepared positively charged polyethyleneimine (PEI)coated HSA (PEI-HSA) nanoparticles via covalent bonding between the carboxyl group of albumin nanoparticles and the amine group of PEI using EDC and $N$-hydroxysuccinimide (NHS). Electrostatic adsorption of gallic acid (GA) on the surface of PEI-HSA nanoparticles leads to the formation of GA-loaded PEI-HSA (GA-PEI-HSA) nanoparticles of diameters $117 \mathrm{~nm}$ and $180 \mathrm{~nm}$. Loading capacity depends on the size of the PEI-HSA nanoparticles and the ratio of GA to nanoparticles [50]. Compared with plain HSA nanoparticles, Mohammad-Beigi et al. [50] found enhanced loading of GA onto PEI-HSA nanoparticles. The significant burst release of $86 \%$ GA, observed for GA-HSA nanoparticles in $1 \mathrm{~h}$, may be due to the electrostatic repulsion between GA and HSA nanoparticles, while about $30 \%$ of burst release in $1.5 \mathrm{~h}$, with sustained release of about $50 \%$ of GA in $48 \mathrm{~h}$, was observed in the case of PEI-coated HSA nanoparticles. Cytotoxic studies of GA-PEI-HSA nanoparticles at high concentration showed no significant toxicity to PC-12 cells, suggesting a very slow release of GA from the nanoparticles [50].
Doxorubicin has numerous side effects, including causing heart failure. To reduce its deleterious effects, various delivery systems have been developed. Abbasi et al. [51] developed doxorubicin-loaded PEI-enhanced cationic HSA nanoparticles with a diameter of about $137 \mathrm{~nm}$ to improve the therapeutic index and to reduce the deleterious side effects of doxorubicin. The positive surface charge is considered to improve the penetration of nanoparticles into cells, which results in an increase in cell transfection. The cytotoxic results against breast cancer cells (MCF-7) exhibit a greater decrease in cell viability for doxorubicin-loaded PEI-HSA-NPs compared with doxorubicin-HSA-NPs and plain doxorubicin after $144 \mathrm{~h}$ [51].

A modified desolvation process, which involves the ultrasonication of tamoxifen-HSA solution prior to the addition of desolvating agent (ethanol), was adopted to form tamoxifenHSA nanoparticles, with an enhanced drug entrapment efficiency of $10 \%$ and drug-loading capacity of $2 \%$ [52]. A polyethylene glycol (PEG) modification (PEGylation) of tamoxifen-HSA nanoparticles was achieved using maleimide (Mal)-PEG5000-NHS, involving the reaction of free amino groups available on the nanoparticles with the NHS ester end of Mal-PEG-NHS. The release of tamoxifen was studied in vitro at $\mathrm{pH} 7.4$ (PBS) in the presence of sodium dodecyl sulfate for PEGylated and non-PEGylated tamoxifen-HSA nanoparticles at $4{ }^{\circ} \mathrm{C}$ and $37^{\circ} \mathrm{C}$ [52]. A slower burst release with sustained release of tamoxifen up to $95 \mathrm{~h}$ was observed for PEGylated HSA nanoparticles compared with non-PEGylated HSA nanoparticles, which showed a cumulative $100 \%$ release of tamoxifen in $78 \mathrm{~h}$. The prepared nanoparticles showed no significant change in their physicochemical properties for up to 6 weeks. A slight increase in particle diameter from $195 \mathrm{~nm}$ to $213 \mathrm{~nm}$ was observed after storage for 3 months at room temperature [52].

Using a desolvation process, $\mathrm{Li}$ et al. [53] optimized the preparation of oridonin-loaded galactosylated-BSA nanoparticles (oridonin-GM-NPs) having a diameter of $200 \mathrm{~nm}$, surface charge of $-30 \mathrm{mV}$, entrapment efficiency of $63 \%$, and loading capacity of $5 \%$. Galactosylated-BSA nanoparticles (GM-NPs) were synthesized via an amidation coupling between the free amino groups of BSA and lactobionic acid using EDC and NHS. The in vitro oridonin release profile in PBS ( $\mathrm{pH}$ 7.4) for oridonin-BSA-NPs and oridonin-GM-NPs shows an initial burst, followed by the sustained release of oridonin up to $70 \mathrm{~h}$, with no significant difference between the two nanoparticles [53]. The specific ability of galactosamine to recognize and bind to the receptors present on the hepatoma cell surface motivated Shen et al. [54] to prepare doxorubicin-loaded galactosaminecontaining albumin nanoparticles (GAL-doxorubicin-ANs) for the targeted delivery of doxorubicin to liver cancer cells. The 
desolvation process involving glutaraldehyde cross-linking was used to prepare spherical nanoparticles of about $200 \mathrm{~nm}$. They found enhanced ability of GAL-doxorubicin-AN to inhibit the growth of HepG2 cells, compared with doxorubicin-AN, through the rapid internalization of nanoparticles into HepG2 via the formation of a ligand (GAL)-receptor complex. A very slow release of doxorubicin (only $12 \%$ in $160 \mathrm{~h}$ ) in the absence of trypsin reduces the side effect of chemotherapy, making GAL-AN an ideal carrier for targeted therapy for liver cancer [54].

Due to the inherent ability of gold nanorods to absorb near-infrared (IR) light [55, 56], Peralta et al. [57] used desolvation and a cross-linking approach to prepare gold nanorod-encapsulated HSA (AuNR-HSA) nanocarrier of diameter $100-300 \mathrm{~nm}$ to provide combined therapy (targeted chemotherapy and photothermal therapy) for the treatment of cancer. They loaded paclitaxel onto the nanocarrier to form paclitaxel-AuNR-HSA nanoparticles. After irradiation with near-IR light for only $15 \mathrm{~min}$, the temperature of the bulk nanoparticle solution reaches $46{ }^{\circ} \mathrm{C}$, which provides cellular hyperthermic action. A 4T1 mouse breast cancer cell showed $94 \%$ of cell death after irradiation with near-IR light for only 1 session of $15 \mathrm{~min}$, while only $82 \%$ cell death was found without irradiation. The enhanced cytotoxic effect is due to the combined therapy in which paclitaxel-resistant cells are killed through hyperthermia, while cells that are resistant to heat are killed by the chemotherapeutic action of paclitaxel. In addition to the hyperthermic action, the photothermal approach also triggers the release of paclitaxel to the targeted tumor sites [57]. Table 2 shows the characterization, target indications, drug release pattern, and cytotoxicity of albumin and the functionalized albumin nanoparticles prepared by the desolvation process.

\section{Emulsification method}

Emulsification, one of the most established methods for preparing polymeric nanoparticles, has been effectively used to produce albumin nanoparticles $[69,70]$. The single emulsion method (Figure 6), involves the high-speed homogenization/ ultrasonication of the mixture formed by adding an aqueous phase containing albumin to an oily organic phase. The nanoemulsion thus formed can be stabilized through chemical cross-linking with glutaraldehyde or thermal treatment by heating to temperatures $>120{ }^{\circ} \mathrm{C}[71,72]$. Solvent diffusion and low-pressure solvent evaporation (using a rotary evaporator) are generally used to remove the organic solvents [73]. The nanoparticles collected after ultracentrifugation can be freeze-dried to obtain albumin nanopowder.
The emulsion-solvent evaporation technique was used successfully to prepare paclitaxel-loaded HSA nanoparticles. The process involves the high-pressure homogenization of an emulsion formed by mixing an organic phase containing paclitaxel in $\mathrm{CHCl}_{3}-\mathrm{C}_{2} \mathrm{H}_{5} \mathrm{OH}$ with an aqueous solution of albumin [19]. The results showed that homogenization pressure of $>15,000$ psi with 12 homogenization cycles produced nanoparticles of minimum size (248 $\mathrm{nm}$ diameter) with a surface charge of $-18 \mathrm{mV}$. The particle diameter increased with increasing HSA concentration, while an inverse trend in zeta potential was observed. Variations in $\mathrm{CHCl}_{3}-\mathrm{C}_{2} \mathrm{H}_{5} \mathrm{OH}$ (94:6) concentration from $3 \%$ to $10 \%$ in HSA emulsion showed that the particle diameter decreased with an increase in $\mathrm{CHCl}_{3}-\mathrm{C}_{2} \mathrm{H}_{5} \mathrm{OH}$ concentration. An inverse trend in particle diameter was observed on increasing the amount of paclitaxel. The release of paclitaxel from paclitaxel-HSA-NPs in vitro exhibited an initial burst, followed by sustained release of $63 \%$ of paclitaxel in $48 \mathrm{~h}$. The prepared nanoparticles showed drug concentration-dependent cell toxicity toward the human breast cancer cell line MCF-7 [19].

10-Hydroxycamptothecin (HCPT) exhibits minimum anticancer activity in its carboxylate form. To improve the anticancer activity and stability of HCPT in its lactone form, Lei et al. [74] prepared HCPT-entrapped BSA nanoparticles to target hepatocarcinomas using a modified emulsion-heat stabilization technique. The nanoparticles were prepared by adding an aqueous solution of HCPT and BSA in $\mathrm{NaOH}$ to castor oil containing Span 80 with stirring, followed by homogenization at high pressure. The resultant emulsion was added dropwise to preheated $\left(140^{\circ} \mathrm{C}\right)$ castor oil for thermal cross-linking. In the resultant BSA nanoparticles, concentration of the lactone form of HCPT could be improved by $95 \%$. Under optimized preparation conditions, the mean diameter of the spherical nanoparticles was $600 \mathrm{~nm}$, with HCPT loading of $2.21 \%$ and encapsulation efficiency of $58 \%$. More than $90 \%$ release of HCPT in vitro was found at $\mathrm{pH} 7.4$ in trypsin medium. A body distribution analysis found a higher concentration of the lactone form of HCPT in the liver, compared with the concentration in the kidney and heart [74].

Guo et al. [75] reported teniposide-loaded HSA nanoparticles (HSA-teniposide-NPs) produced by ultrasonically mixing organic and aqueous phases. The HSA-teniposide-NPs obtained after solvent evaporation were coated with poly(Lglutamic acid)-g-methoxy PEG (P) and chitosan (CS) polymers to obtain 2-layered coated albumin nanoparticles (P-CS-NP). The multilayered teniposide-loaded HSA nanoparticles of diameter $80 \mathrm{~nm}$ and zeta potential of $-4 \mathrm{mV}$ exhibited 2.2\% effective loading capacity and $61 \%$ entrapment efficiency. The teniposide release was studied at $\mathrm{pH} 5.5,6.8$, and 7.4 in 
Table 2. Characterization, target indications, drug release pattern, and cytotoxicity of albumin and functionalized albumin nanoparticles prepared by desolvation process

\begin{tabular}{|c|c|c|c|c|c|}
\hline Albumin used & $\begin{array}{l}\text { Functionalizing or } \\
\text { conjugating agent }\end{array}$ & $\begin{array}{l}\text { Drug or } \\
\text { antioxidant loaded }\end{array}$ & $\begin{array}{l}\text { Target } \\
\text { indication }\end{array}$ & Outcome or applicationt & Reference \\
\hline Egg albumin & - & Curcumin (CUR) & - & $\begin{array}{l}\text { - Particle diameter: } 232 \mathrm{~nm}, \mathrm{DLC}: 4.125 \% \text {, } \\
\text { DEE: } 55 \% \\
\text { - Enhanced solubility of CUR } \\
\text { - RSM was used for process optimization }\end{array}$ & [32] \\
\hline HSA & - & Doxorubicin & $\begin{array}{l}\text { Neuroblastoma } \\
\text { (UKF-NB3 and } \\
\text { IMR-32 cell } \\
\text { lines) }\end{array}$ & $\begin{array}{l}\text { Particle diameter: } 158.5 \mathrm{~nm}, \mathrm{ZP}:-31.9 \mathrm{mV} \text {, } \\
\text { DEE: } 95 \% \\
\text { - Stable up to } 6 \text { months at } 4{ }^{\circ} \mathrm{C} \\
\text { - Increased inhibition of UKF-NB3 and } \\
\text { IMR-32 cell lines, compared with free } \\
\text { doxorubicin }\end{array}$ & [43] \\
\hline BSA & - & Ginsenoside CK & $\begin{array}{l}\text { Lung, skin, } \\
\text { colon cancer, } \\
\text { and hepatocar- } \\
\text { cinoma (A549, } \\
\text { HaCaT, HT29, } \\
\text { and HepG2 cell } \\
\text { lines) }\end{array}$ & $\begin{array}{l}\text { - Particle diameter: } 30-50 \mathrm{~nm}, \mathrm{ZP}:-70.8 \mathrm{mV} \text {. } \\
\text { - Nanoparticles were stable at biological } \\
\text { pH and were readily degraded in acidic } \\
\text { conditions, enhanced water solubility of } \\
\text { ginsenoside CK. } \\
\text { - Increased antiproliferative activity toward } \\
\text { HT29, A546, HepG2, and HaCaT cancer cell } \\
\text { lines. }\end{array}$ & [44] \\
\hline BSA & - & Salicylic acid (SA) & - & $\begin{array}{l}\text { Particle diameter: } 110 \mathrm{~nm}, \mathrm{ZP}:-33.2 \mathrm{mV} \text {, } \\
\text { DEE: } 55 \% \text { at pH } 7.4 \\
\text { - Increases the bioavailability of SA } \\
\text { - Instant release, progressive up to } 120 \mathrm{~min} \text {, } \\
\text { then constant release of SA up to } 400 \mathrm{~min}\end{array}$ & [33] \\
\hline BSA & Folic acid & Tamoxifen (TMX) & Breast cancer & $\begin{array}{l}\text { - Particle diameter: } 76-417 \mathrm{~nm}, \mathrm{ZP}:-10 \text { to } \\
-43 \mathrm{mV} \\
\text { - } \text { Folic acid: for selective delivery of TMX } \\
\text { - Rapid in the first } 2 \mathrm{~h} \text {, followed by sustained } \\
\text { release of TMX up to } 24 \mathrm{~h} \text {. Enhanced } \\
\text { release in acidic conditions } \\
\text { - Enhanced cellular uptake and effective in } \\
\text { reducing carcinoma cell survival }\end{array}$ & [46] \\
\hline BSA & Folic acid & Bexarotene (BXT) & $\begin{array}{l}\text { Breast cancer } \\
\text { (MCF-7 cell } \\
\text { line) }\end{array}$ & $\begin{array}{l}\text { Particle diameter: } 195.3 \mathrm{~nm}, \mathrm{ZP}:-33.64 \mathrm{mV} \text {, } \\
\text { DEE: } 65 \%, \mathrm{DLC}: 1.7 \% \\
\text { Folate receptors are overexpressed in } \\
\text { MCF-7 } \\
\text { - Initial burst release ( } 39 \% \text { in } 12 \mathrm{~h} \text { ), followed } \\
\text { by up to } 69 \% \text { of slow release of BXT in } 48 \mathrm{~h} \text {, } \\
\text { then sustained release up to } 72 \mathrm{~h} \\
\text { - Greater antiproliferative effect on MCF-7 } \\
\text { cells }\end{array}$ & [47] \\
\hline HSA & $\begin{array}{l}\text { Folic acid and } \\
\text { magnetic } \\
\text { nanoparticles }\end{array}$ & Cisplatin & - & $\begin{array}{l}\text { Particle diameter: } 9 \mathrm{~nm}, \mathrm{DLC}: 5.3 \%, \mathrm{DEE}: \\
90 \% \\
\text { - Folate receptors are overexpressed in } \\
\text { cancer cells } \\
\text { - Sustained release of cisplatin for } 24 \mathrm{~h} \\
\text { without burst release } \\
\text { - The nanocarrier has selective chemothe- } \\
\text { rapy action, along with thermotherapy }\end{array}$ & [48] \\
\hline
\end{tabular}


Table 2. Continued

\begin{tabular}{|c|c|c|c|c|c|}
\hline Albumin used & $\begin{array}{l}\text { Functionalizing or } \\
\text { conjugating agent }\end{array}$ & $\begin{array}{l}\text { Drug or } \\
\text { antioxidant loaded }\end{array}$ & $\begin{array}{l}\text { Target } \\
\text { indication }\end{array}$ & Outcome or applicationt & Reference \\
\hline BSA & Folic acid & Chrysin (CHA) & $\begin{array}{l}\text { Breast cancer } \\
\text { (MCF-7 cell } \\
\text { line) }\end{array}$ & $\begin{array}{l}\text { Particle diameter: } 97.5 \mathrm{~nm}, \mathrm{ZP}:-11.0 \mathrm{mV} \\
\text { - } \text { Folate receptors are overexpressed in } \\
\text { cancer cells } \\
\text { - Initial burst ( } 20 \%) \text { in } 10 \mathrm{~h} \text {, followed by } \\
\text { cumulative } 57 \% \text { sustained release of } \mathrm{CHA} \\
\text { up to } 96 \mathrm{~h} \\
\text { - Enhanced cellular uptake and cytotoxicity } \\
\text { toward MCF-7 cell line }\end{array}$ & [49] \\
\hline HSA & PEI & Gallic acid (GA) & $\begin{array}{l}\text { Parkinson } \\
\text { disease } \\
\text { (PC-12 neuro- } \\
\text { endocrine cell } \\
\text { line) }\end{array}$ & $\begin{array}{l}\text { - Particle diameter: } 117 \mathrm{~nm} \text { and } 180 \mathrm{~nm}, \mathrm{ZP} \text { : } \\
+35.2 \mathrm{mV} \text { and }+34.2 \mathrm{mV} \text {, respectively } \\
\text { - } \mathrm{DLC} \text { and DEE depend on GA-to-PEI-HSA } \\
\text { ratio, } \\
\text { - Initial burst ( } 30 \%) \text { in } 1.5 \mathrm{~h} \text {, followed by } \\
\text { sustained release of GA up to } 48 \mathrm{~h} \text {. } \\
\text { - No significant toxicity toward PC- } 12 \text { cells }\end{array}$ & [50] \\
\hline HSA & PEI & Doxorubicin & $\begin{array}{l}\text { Breast cancer } \\
\text { (MCF-7 cell } \\
\text { line) }\end{array}$ & $\begin{array}{l}\text { - Particle diameter: } 137 \mathrm{~nm}, \mathrm{ZP}:+15 \mathrm{mV} \\
\text { - } 80 \% \text { of cells were transfected due to posi- } \\
\text { tive surface charge } \\
\text { - } \text { Exhibited greater cytotoxic effect against } \\
\text { MCF-7 cancer cell lines }\end{array}$ & [51] \\
\hline HSA & PEG & Tamoxifen (TMX) & Tumor target & $\begin{array}{l}\text { Particle diameter: } 195 \mathrm{~nm}, \mathrm{ZP}:-21 \mathrm{mV}, \mathrm{DEE} \text { : } \\
74 \%, \mathrm{DLC}: 7 \% \\
\text { - Only a slight increase in particle size after } \\
3 \text { months of storage } \\
\text { - Ultrasonication of TMX-HSA mixture was } \\
\text { done before desolvation }\end{array}$ & [52] \\
\hline BSA & Lactobionic acid & Oridonin (ORI) & Liver cancer & $\begin{array}{l}\text { Particle diameter: } 200 \mathrm{~nm}, \mathrm{ZP}:-30 \mathrm{mV}, \mathrm{DLC} \text { : } \\
5 \%, \mathrm{DEE}: 63 \% \\
\text { - Galactosylated BSA: for selective liver } \\
\text { targeting } \\
\text { - Initial burst, followed by sustained release } \\
\text { of ORI up to } 70 \mathrm{~h} \text {. }\end{array}$ & [53] \\
\hline BSA & Galactosamine & Doxorubicin (DOX) & $\begin{array}{l}\text { Hepatocarci- } \\
\text { noma (HepG2 } \\
\text { cell line) }\end{array}$ & $\begin{array}{l}\text { Particle diameter: } 200 \mathrm{~nm}, \mathrm{ZP}:-16.1 \mathrm{mV} \text {, } \\
\text { DEE: } 58 \%, \mathrm{DLC}: 2 \% \\
\text { - Asialoglycoprotein receptors are overex- } \\
\text { pressed in HepG2 cells } \\
\text { - Slow release ( } 5 \% \text { in } 5 \mathrm{~h} \text { ), followed by } 12 \% \\
\text { sustained release of DOX up to } 160 \mathrm{~h} \\
\text { - Increased cellular uptake causes more } \\
\text { cytotoxicity toward HepG2 cells. }\end{array}$ & [54] \\
\hline HSA & - & $\begin{array}{l}\text { Paclitaxel and gold } \\
\text { nanorods }\end{array}$ & $\begin{array}{l}\text { Breast cancer } \\
\text { ( } 4 \mathrm{~T} 1 \text { cell line in } \\
\text { mouse) }\end{array}$ & $\begin{array}{l}\text { Particle diameter: } 221 \mathrm{~nm}, \mathrm{ZP}:-45 \mathrm{mV} \text {, } \\
\text { DEE: } 92 \% \\
\text { combined (chemo + photothermal) } \\
\text { therapy } \\
\text { - } 94 \% \text { of } 4 \mathrm{~T} 1 \text { cell death on } 15 \text {-min exposure } \\
\text { to near-infrared light }\end{array}$ & [57] \\
\hline BSA & $\begin{array}{l}\text { Polycaprolactone } \\
(\mathrm{PCL})\end{array}$ & Albendazole (ABZ) & $\begin{array}{l}\text { Pancreatic } \\
\text { cancer }\end{array}$ & $\begin{array}{l}\text { Particle diameter: } 10 \text { and } 200 \mathrm{~nm} \text {, DEE: } 68 \% \\
\text { (10 } \mathrm{nm} \text { ) and } 81 \% \text { (100 } \mathrm{nm}) \\
\text { BSA-PCL nanoparticles of } 200 \mathrm{~nm} \text { effec- } \\
\text { tively deliver ABZ to pancreatic cells and } \\
\text { show a greater antiproliferative effect on } \\
\text { cancer cells }\end{array}$ & [58] \\
\hline
\end{tabular}


Table 2. Continued

\begin{tabular}{|c|c|c|c|c|c|}
\hline Albumin used & $\begin{array}{l}\text { Functionalizing or } \\
\text { conjugating agent }\end{array}$ & $\begin{array}{l}\text { Drug or } \\
\text { antioxidant loaded }\end{array}$ & $\begin{array}{l}\text { Target } \\
\text { indication }\end{array}$ & Outcome or applicationt & Reference \\
\hline HSA & SP and PEG & Paclitaxel (PTX) & Brain cancer & $\begin{array}{l}\text { Particle diameter: } 150 \mathrm{~nm}, \mathrm{ZP}:-12.0 \mathrm{mV} \text {, } \\
\text { DLC: } 8 \%, \mathrm{DEE}: 86 \% \\
\text { - Substance P (SP) receptors are overex- } \\
\text { pressed in glioma sites } \\
\text { - Initial burst ( } 40 \% \text { ), followed by the sustai- } \\
\text { ned release of PTX up to } 48 \mathrm{~h} \\
\text { - The targeting effect of SP increases the } \\
\text { cellular uptake and nanoparticles exhibit } \\
\text { strong antitumor effect toward U87 cells }\end{array}$ & [59] \\
\hline BSA & $\begin{array}{l}\text { Magnetic } \\
\text { nanoparticles }\end{array}$ & - & - & $\begin{array}{l}\text { - Particle diameter: } 70-95 \mathrm{~nm}, \mathrm{ZP}:-9.38 \mathrm{mV} \\
\text { - Biocompatible and do not show a toxic } \\
\text { effect on HFF2 cell lines } \\
\text { - Can be used in MRI technique and chemo- } \\
\text { thermotherapy }\end{array}$ & [60] \\
\hline BSA & $\begin{array}{l}\text { Magnetic } \\
\text { nanoparticles }\end{array}$ & Curcumin (CUR) & $\begin{array}{l}\text { Breast cancer } \\
\text { (MCF-7 cell } \\
\text { line) }\end{array}$ & $\begin{array}{l}\text { Particle diameter: } 56 \mathrm{~nm}, \mathrm{ZP}:-10.1 \mathrm{mV} \text {, } \\
\text { DLC: } 7 \% \\
\text { Initial burst, followed by sustained release } \\
\text { of CUR up to } 160 \mathrm{~h} \text {. Enhanced release in } \\
\text { acidic conditions } \\
\text { - Biocompatible and showed a significant } \\
\text { cytotoxic effect on MCF-7 cells }\end{array}$ & [61] \\
\hline BSA & - & Curcumin (CUR) & $\begin{array}{l}\text { Breast cancer } \\
\text { (MDA-MB-231 } \\
\text { cell line) }\end{array}$ & $\begin{array}{l}\text { Particle diameter: } 223.5 \mathrm{~nm}, \mathrm{ZP}:-31.7 \mathrm{mV} \text {, } \\
\text { at drug polymer ratio of 1:2, DEE: } 91 \% \text {. } \\
\text { - Enhancement in the solubility of CUR } \\
\text { - Initial burst ( } 23 \%) \text { in } 24 \mathrm{~h} \text {, followed by the } \\
\text { sustained release of CUR up to } 30 \text { days } \\
\text { - Enhanced antiproliferative effect toward } \\
\text { MDA-MB-231 }\end{array}$ & [62] \\
\hline Egg albumin & - & $\begin{array}{l}\text { Gallic acid } \\
\text { (GA) }\end{array}$ & Brain cancer & $\begin{array}{l}\text { Particle diameter: } 150 \mathrm{~nm}, \mathrm{ZP}:-30 \mathrm{mV}, \mathrm{DLC} \text { : } \\
28 \%, \mathrm{DEE}: 91 \% \\
\text { - A good candidate for brain-targeted drug } \\
\text { delivery system }\end{array}$ & [63] \\
\hline BSA & - & $\begin{array}{l}\text { Sulfasalazine } \\
\text { (SSZ) }\end{array}$ & - & $\begin{array}{l}\text { Particle diameter: } 208-381 \mathrm{~nm}, \mathrm{ZP}:-24.6 \text { to } \\
-36.3 \mathrm{mV}, \mathrm{DLC}: 0.5 \%, \mathrm{DEE}: 28 \% \\
\text { - Enhanced solubility of SSZ }\end{array}$ & [64] \\
\hline BSA & - & Curcumin (CUR) & $\begin{array}{l}\text { Breast cancer } \\
\text { (MCF-7 cell } \\
\text { line) }\end{array}$ & $\begin{array}{l}\text { Particle diameter: } 92.6 \mathrm{~nm}, \mathrm{ZP}:-9.2 \mathrm{mV} \text {, } \\
\text { DLC: } 2.2 \%, \mathrm{DEE}: 78 \% \\
\text { Rapid in } 10 \mathrm{~h}(20 \%) \text {, followed by controlled } \\
\text { release of } 30 \% \text { of CUR up to } 96 \mathrm{~h} \\
\text { - Cytotoxic toward MCF-7, inhibitory effect } \\
\text { increases with time }\end{array}$ & {$[65]$} \\
\hline HSA & - & $\begin{array}{l}\text { Doxorubicin (DXR), } \\
\text { daunorubicin (DNR), } \\
\text { pirarubicin (THP), } \\
\text { and aclarubicin } \\
\text { (ACR) }\end{array}$ & $\begin{array}{l}\text { Breast cancer } \\
\text { (MCF-7 cell } \\
\text { line) }\end{array}$ & $\begin{array}{l}\text { DXR-HSA-NPs: particle diameter: } 108 \mathrm{~nm} \text {, } \\
\text { ZP: }-35 \text { mV, DLC: } 4 \% \text {, DEE: } 96 \% \\
\text { DNR-HSA-NPs: particle diameter: } 109 \mathrm{~nm} \text {, } \\
\text { ZP: }-33 \text { mV, DLC: } 6 \%, \text { DEE: } 97 \% \\
\text { THP-HSA-NPs: particle diameter: } 121 \mathrm{~nm} \text {, } \\
\text { ZP: }-43 \text { mV, DLC: } 2.6 \%, \text { DEE: } 88 \% \\
\text { - ACR-HSA-NPs: particle diameter: } 119 \mathrm{~nm} \text {, } \\
\text { ZP: }-45 \text { mV, DLC: } 1 \%, \text { DEE: } 30 \% \\
\text { - All anthracycline-HSA-NPs exhibit cytotoxi- } \\
\text { city toward MCF-7 and HepG2 cells }\end{array}$ & [66] \\
\hline
\end{tabular}


Table 2. Continued

\begin{tabular}{|c|c|c|c|c|c|}
\hline Albumin used & $\begin{array}{l}\text { Functionalizing or } \\
\text { conjugating agent }\end{array}$ & $\begin{array}{l}\text { Drug or } \\
\text { antioxidant loaded }\end{array}$ & $\begin{array}{l}\text { Target } \\
\text { indication }\end{array}$ & Outcome or applicationt & Reference \\
\hline $\mathrm{HSA}$ & - & $\begin{array}{l}\text { Pyrazolo[3,4-d] } \\
\text { pyrimidine }\end{array}$ & $\begin{array}{l}\text { Neuroblastoma } \\
\text { (SH-SY5Y cell } \\
\text { line) }\end{array}$ & $\begin{array}{l}\text { Particle diameter: 50-115 nm, ZP: }-29.9 \\
\text { mV, DEE: } 40 \%-99.5 \% ., \text { DLC: 39\%-95\% } \\
\text { - Improved drug solubility } \\
\text { - Enhanced antiproliferative effect on } \\
\text { SH-SY5Y. }\end{array}$ & [67] \\
\hline BSA & Folic acid & $\begin{array}{l}\text { Curcumin difluori- } \\
\text { nated (CDF) }\end{array}$ & $\begin{array}{l}\text { Ovarian cancer } \\
\text { (SKOV } 3 \text { cell } \\
\text { line) }\end{array}$ & $\begin{array}{l}\text { - Particle diameter: } 279 \mathrm{~nm}, \mathrm{ZP}:-45.9 \mathrm{mV} \text {, } \\
\text { DEE: } 78 \%, \text { DLC: } 38 \% \\
\text { - Higher cellular uptake causes enhanced } \\
\text { cytotoxicity }\end{array}$ & [68] \\
\hline
\end{tabular}

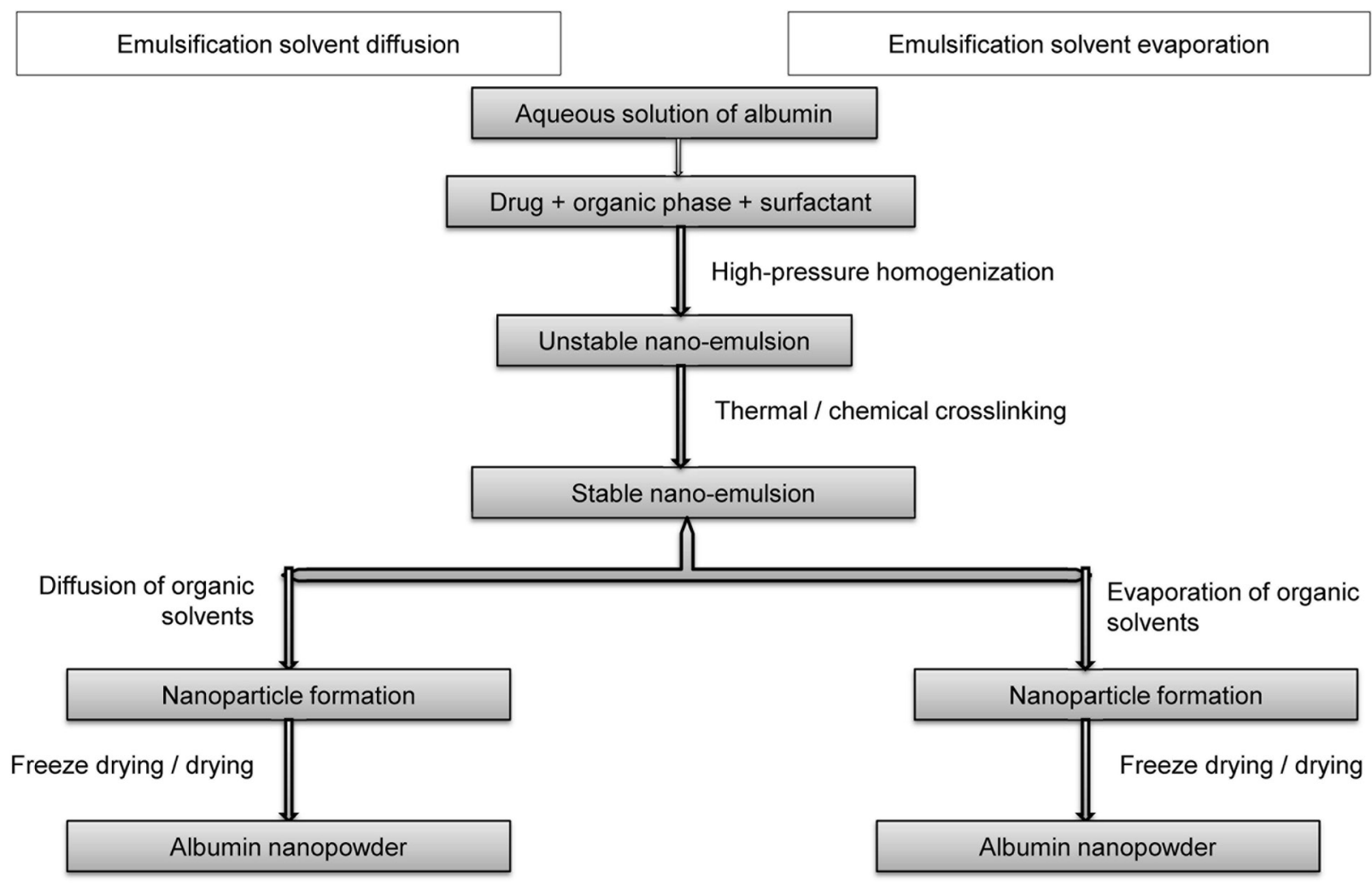

Figure 6. Preparation of drug-loaded albumin nanoparticles using emulsification.

phosphate-buffered conditions; the maximum release of teniposide $(80 \%)$ observed at $\mathrm{pH} 6.8$ was due mainly to the multilayered structure [75]. The reduced solubility of chitosan at $\mathrm{pH}$ 7.4 reduces drug diffusion, while the lower solubility of HSA around $\mathrm{pH} 5.5$ causes unfavorable release. The coated albumin nanoparticles exhibited a lower cellular uptake compared with the naked particles, possibly explained by the interference of the coated layer with albumin uptake receptors. The multilayered nanoparticles showed reduced antitumor efficacy toward lung cancer cell lines. The distribution of P-CS-NP in vivo showed significant accumulation in the lung, by contrast with teniposide in solution, which was mainly accumulated in 
the liver and spleen. The prolonged circulation in plasma and higher accumulation in the lung makes P-CS-NP a promising candidate for the passive and controlled delivery of teniposide to the lung [75].

The double emulsion method used by Zhang and Zhu [76] to prepare BSA-loaded poly(D,L-lactic-co-glycolic acid) (PLGA) microspheres. First, a water-in-oil emulsion was produced by emulsifying the internal aqueous phase solution of BSA (in PBS) with PLGA solution in methylene chloride under stirring. The primary emulsion thus formed was then poured into an external aqueous phase solution of Tween 80 under vigorous stirring. The solvent was evaporated from the resultant double emulsion by magnetic stirring for 3-5 h [76]. BSA entrapment of $76 \%$ and $89 \%$ with a smooth microsphere surface could be achieved by adding $\mathrm{NaCl}$ and glucose, respectively, in the continuous phase. The addition of $\mathrm{NaCl} /$ glucose in the Tween 80 external phase produced microspheres with high BSA entrapment. The enhanced burst release of BSA was observed due to the nonporous nature of microspheres prepared without additives $(\mathrm{NaCl} /$ glucose) [76]. Table 3 demonstrates the characterization, target indications, drug release pattern, and cytotoxicity of albumin and the functionalized albumin nanoparticles prepared by emulsification.

\section{Thermal gelation}

Thermal gelation is a heat-induced process used to produce protein nanoparticles (Figure 7). The gelation process involves the irreversible heat-induced conformation transition from $\alpha$-helix to $\beta$-sheet, followed by the aggregation of $\beta$-sheet via protein-protein interactions, including hydrophobic and electrostatic interactions, hydrogen bonding, and disulfidesulfhydryl interchange reactions [3, 70]. A Fourier-transform IR spectroscopy study of BSA during heating at $80-85^{\circ} \mathrm{C}$ found that most of the helical structure is disrupted, and irreversible intermolecular $\beta$-sheets are formed [80].

Novel interpolymeric (chitosan-ovalbumin) nanoparticles stabilized with PEG400 were prepared by heat coagulation for the oral delivery of alprazolam [81]. Alprazolam-loaded nanoparticles exhibited $259.6 \mathrm{~nm}$ diameter and $-9.0 \mathrm{mV}$ zeta potential in the presence of PEG400 when the mixture of alprazolam containing chitosan and egg albumin was heated at $80{ }^{\circ} \mathrm{C}$ for $30 \mathrm{~min}$. The interpolymeric nanoparticles can load $99.4 \%$ of alprazolam in the presence of $0.5 \mathrm{~mL}$ PEG 400 , $80 \mathrm{mg}$ ovalbumin, and $80 \mathrm{mg}$ chitosan with $30 \mathrm{~min}$ of heating at $80^{\circ} \mathrm{C}$. The sustained release of alprazolam over $24 \mathrm{~h}$ makes it a promising carrier for the sustained release of several lipophilic drugs [81]. Table 4 demonstrates the characterization, target indications, drug release pattern, and cytotoxicity of albumin and functionalized albumin nanoparticles prepared by thermal gelation.

\section{Nanoparticle albumin-bound (nab) technology}

The United States Food and Drug Administration approval of nab-paclitaxel has spurred many researchers to use nab technology to develop targeted anticancer drug delivery systems. It is an ideal technology for the encapsulation of lipophilic anticancer drugs in a protein matrix for effective delivery [3]. To prepare a nab drug, an aqueous solution of albumin is mixed using low rotation with a drug in the organic phase (chloroform/acetone + chloroform) to form a crude emulsion, which produces the final nanoemulsion on high-pressure homogenization. Organic solvents are removed from the resultant colloid by rotary evaporation under vacuum. The nanoparticles obtained are then centrifuged or filtered (syringe filter), and the supernatant collected is lyophilized to obtain the albumin nanopowder [84, 85]. Figure 8 shows a schematic representation of the nab technology used to produce albuminbased nanoparticles.

$\mathrm{Nab}$ technology was successfully used to prepare injection-based tacrolimus-loaded HSA nanoparticles (tacrolimusHSA-NPs) having enhanced targetability toward rheumatoid arthritis tissues [84]. Tacrolimus-HSA-NPs were prepared by mixing an aqueous solution of HSA with tacrolimus and cholesterol (dissolved in the mixture of ethanol and chloroform separately) at low rotation, followed by homogenization at high pressure. After removal of chloroform using rotary evaporation under reduced pressure, the resulting nanoparticles were centrifuged, and the collected supernatant was lyophilized to obtain tacrolimus-HSA-NPs [85]. The nanoparticles had diameter of $185.8 \mathrm{~nm}$, zeta potential of $-30.5 \mathrm{mV}, 79 \%$ entrapment efficiency, and $1.5 \%$ tacrolimus loading capacity. Tacrolimus-HSA-NPs showed 46 times enhanced water solubility with $94 \%$ slow release of tacrolimus in $24 \mathrm{~h}$ compared with free TAC. Studies in arthritic mice in vivo showed that tacrolimus-HSA-NPs accumulated significantly at the inflamed hind paws of mice with collagen-induced arthritis until $24 \mathrm{~h}$, whereas it did not accumulate markedly at the paw site in normal mice, thereby exhibiting increased antiarthritic activity compared with other tacrolimus formulations [84].

Gemcitabine-loaded albumin nanoparticles prepared by desolvation show poor solubility, nonreproducibility, and lack of uniformity. Yu et al. addressed these problems by preparing gemcitabine-loaded HSA nanoparticles using nab technology to treat pancreatic cancer [85]. Gemcitabine-HSA-NPs were prepared by high-pressure homogenization of HSA (in water) and gemcitabine (in aqueous chloroform) at 20,000 psi for 9 
Table 3. Characterization, target indications, drug release pattern, and cytotoxicity of albumin and functionalized albumin nanoparticles prepared by emulsification

\begin{tabular}{|c|c|c|c|c|c|c|}
\hline Albumin used & $\begin{array}{l}\text { Organic phase } \\
\text { and surfactant }\end{array}$ & $\begin{array}{l}\text { Functionalizing } \\
\text { or coating agent }\end{array}$ & $\begin{array}{l}\text { Drug or } \\
\text { antioxidant loaded }\end{array}$ & $\begin{array}{l}\text { Target } \\
\text { indication }\end{array}$ & Outcome or application $\dagger$ & Reference \\
\hline HSA in water & $\begin{array}{l}\text { Chloroform + } \\
\text { ethanol }\end{array}$ & - & Paclitaxel (PTX) & $\begin{array}{l}\text { Breast } \\
\text { cancer } \\
\text { (MCF-7 } \\
\text { cell line) }\end{array}$ & $\begin{array}{l}\text { - } \quad \text { Particle diameter: } 170.2 \mathrm{~nm}, \mathrm{ZP} \text { : } \\
-17.4 \mathrm{mV}, \mathrm{DEE}: 82 \% \\
\text { - } 64 \% \text { of PTX release in } 48 \mathrm{~h} \\
\text { - } \quad \text { Concentration-dependent cell } \\
\text { viability for MCF-7 cells } \\
\text { - } \quad \mathrm{IC}_{50} \text { for PTX-HSA-NPs is } 4.9 \mu \mathrm{m}\end{array}$ & [19] \\
\hline $\mathrm{BSA}$ in $\mathrm{NaOH}$ & $\begin{array}{l}\text { Castor oil + } \\
\text { Span } 80\end{array}$ & - & $\begin{array}{l}\text { 10-Hydroxycampto- } \\
\text { thecin (HCPT) }\end{array}$ & $\begin{array}{l}\text { Liver } \\
\text { cancer }\end{array}$ & $\begin{array}{l}\text { Particle diameter: } 600 \mathrm{~nm}, \mathrm{DEE}: \\
58 \%, \mathrm{DLC}: 2.2 \% \\
\text { - Sustained release of } 90 \% \mathrm{HCPT} \\
\text { at } \mathrm{pH} 7.4 \text { in trypsin medium } \\
\text { - } \text { Higher concentration of HCPT in } \\
\text { liver than in heart and kidney } \\
\text { - } 95 \% \text { of HCPT was present in the } \\
\text { lactone form }\end{array}$ & {$[74]$} \\
\hline HSA in water & $\begin{array}{l}\text { Chloroform } \\
+ \text { acetone }+ \\
\text { cholesterol }\end{array}$ & Chitosan, PLG-PEG & Teniposide (TS) & $\begin{array}{l}\text { Lung } \\
\text { cancer } \\
\text { (A549 } \\
\text { cell line) }\end{array}$ & $\begin{array}{l}\text { - Particle diameter: } 180 \mathrm{~nm}, \mathrm{ZP}: \\
-4 \mathrm{mV}, \mathrm{DEE}: 61 \% ., \mathrm{DLC}: 2.2 \% \\
\text { - } \quad \text { Lower concentration of TS in } \\
\text { heart and kidney } \\
\text { - } 80 \% \text { of TS release in } 72 \mathrm{~h} \\
\text { - } \quad \text { Lower cellular uptake and antitu- } \\
\text { mor efficacy toward A- } 549 \text {. }\end{array}$ & {$[75]$} \\
\hline $\mathrm{BSA}$ in $\mathrm{PBS}\left(\mathrm{w}_{1}\right)$ & $\begin{array}{l}\text { Tween } 80 \text { (o) } \\
\text { Aqueous solu- } \\
\text { tion of PLGA } \\
\left(\mathrm{w}_{2}\right)\end{array}$ & - & - & - & $\begin{array}{l}\text { Double emulsion technique was } \\
\text { used. } \\
\text { - Addition of } \mathrm{NaCl} \text { and glucose } \\
\text { increases entrapment efficiency } \\
\text { and delays the release of BSA } \\
\text { - Tween } 80 \text { increases BSA } \\
\text { entrapment }\end{array}$ & [76] \\
\hline BSA in water & $\begin{array}{l}\mathrm{B}_{\text {mim }} \mathrm{PF}_{6} \\
+ \text { Tween } 20\end{array}$ & Folic acid & - & - & $\begin{array}{l}\text { - } \text { Particle size: } 100 \mathrm{~nm} \text {. } \\
\text { - } \text { Fnhanced cellular uptake } \\
\text { preseceptors are overex- } \\
\text { - Exhibit high cell viability }\end{array}$ & [77] \\
\hline BSA in water & $\begin{array}{l}\text { n-Butanol } \\
+ \text { toluene }+ \\
\text { coconut oil }\end{array}$ & - & - & - & $\begin{array}{l}\text { - Particle diameter: } 269 \mathrm{~nm} \text {. } \\
\text { - } \quad \text { Green method of synthesis }\end{array}$ & [78] \\
\hline HSA in water & $\begin{array}{l}\text { Ethanol + } \\
\text { Tween } 80\end{array}$ & - & Carvacrol & $\begin{array}{l}\text { Gastric } \\
\text { cancer } \\
\text { (AGS cell } \\
\text { line) }\end{array}$ & $\begin{array}{l}\text { Particle diameter: } 230 \mathrm{~nm}, \mathrm{ZP} \text { : } \\
-33.7 \mathrm{mV}, \mathrm{DEE}: 32 \%, \mathrm{DLC}: 32 \% \\
\text { - Initial fast release ( } 27 \% \text { in } 3 \mathrm{~h} \text { ), } \\
\text { followed by sustained release } \\
\text { of carvacrol ( } 80 \% \text { ) up to } 240 \mathrm{~h} \\
\text { - Reduces cell viability (AGS } \\
\text { cell line) to } 50 \% .\end{array}$ & [79] \\
\hline
\end{tabular}

†Particle diameters are approximate; $\mathrm{B}_{\text {mim }} \mathrm{PF}_{6^{\prime}}$ 1-butyl-3-methylimidazolium hexafluorophosphate, $\mathrm{BSA}$, bovine serum albumin; DEE, drug entrapment efficiency (approximate); DLC, drug-loading capacity (approximate); HSA, human serum albumin; $\mathrm{I}_{50}$, half-maximal inhibitory concentration; o, organic phase; PBS, phosphate-buffered saline; PEG, polyethylene glycol; PLG, poly(L-glutamic acid)-g-methoxy; PLGA, poly(D,L-lactic-co-glycolic acid); W1, internal aqueous phase; W2, external aqueous phase; ZP, zeta potential.

cycles. Chloroform was removed, and the colloidal solution was filtered using a $0.25 \mu \mathrm{m}$ membrane syringe filter. The filtrate was lyophilized to obtain gemcitabine-HSA-NP powder.
The vacuum-dried, nearly-spherical nanoparticles of $150 \mathrm{~nm}$ diameter with $-10.2 \mathrm{mV}$ surface charge exhibited $83 \%$ entrapment efficiency and 10\% loading capacity for gemcitabine. 


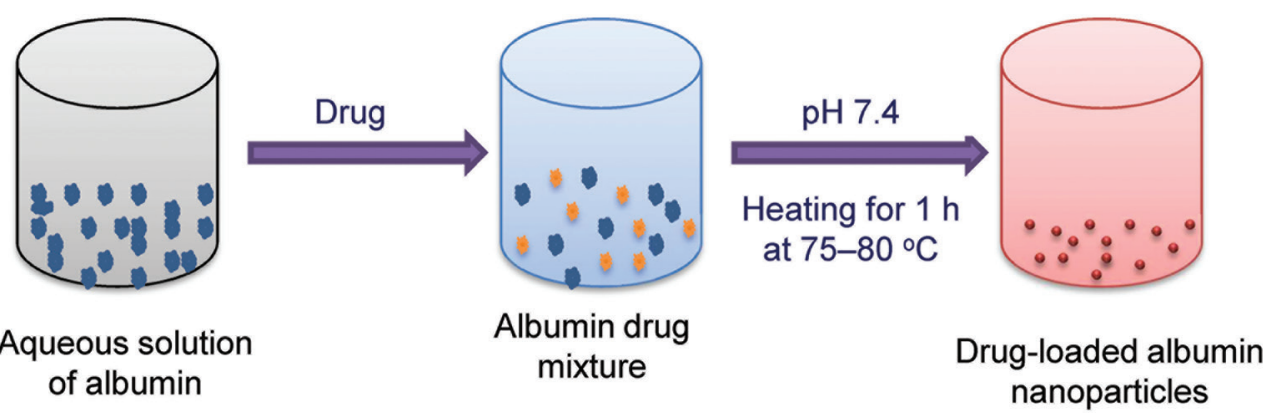

Figure 7. Thermal gelation process for the preparation of drug-loaded albumin nanoparticles.

Table 4. Characterization, target indications, drug release pattern, and cytotoxicity of albumin and functionalized albumin nanoparticles prepared by thermal gelation

\begin{tabular}{|c|c|c|c|c|c|c|}
\hline Albumin used & $\begin{array}{l}\text { Temperature, } \\
\text { time, pH }\end{array}$ & $\begin{array}{l}\text { Functionalizing or } \\
\text { conjugating agent }\end{array}$ & $\begin{array}{l}\text { Drug or antioxi- } \\
\text { dant loaded }\end{array}$ & $\begin{array}{c}\text { Target } \\
\text { indication }\end{array}$ & Outcome or applicationt & Reference \\
\hline $\begin{array}{l}\text { Egg albumin in } \\
\text { water }\end{array}$ & $80^{\circ} \mathrm{C}, 30 \mathrm{~min}, 5.4$ & Chitosan, PEG400 & $\begin{array}{l}\text { Alprazolam } \\
\text { (ALP) }\end{array}$ & - & $\begin{array}{l}\text { Particle diameter: } 260 \mathrm{~nm} \text {, } \\
\text { ZP: }-9.0 \mathrm{mV}, \mathrm{DEE}: 99.4 \% \text {. } \\
\text { Initial burst, then sustai- } \\
\text { ned release of ALP (85\%) } \\
\text { up to } 24 \mathrm{~h} \\
\text { Excellent carrier for sustai- } \\
\text { ned delivery of lipophilic } \\
\text { drugs }\end{array}$ & [81] \\
\hline $\begin{array}{l}\text { Egg albumin in } \\
\text { water }\end{array}$ & $80^{\circ} \mathrm{C}, 30 \mathrm{~min}, 5.4$ & $\begin{array}{l}\text { Chitosan, Carbopol } \\
940\end{array}$ & $\begin{array}{l}\text { Aceclofenac } \\
\text { (ACA) }\end{array}$ & - & $\begin{array}{l}\text { Particle diameter: } 353 \mathrm{~nm} \text {, } \\
\text { ZP: }-22.1 \mathrm{mV} \text { DEE: } 96 \% \text {. } \\
\text { Initial burst, then slow } \\
\text { release of ACA ( } 54 \%-88 \%) \\
\text { in } 8 \mathrm{~h} \\
\text { - Carbopol } 940 \text { gel contai- } \\
\text { ning NPs exhibited faster } \\
\text { permeation of ACA }\end{array}$ & [82] \\
\hline BSA in water & $90^{\circ} \mathrm{C}, 2 \mathrm{~h}, 4.2$ & Chitosan (CS) & $\begin{array}{l}\beta \text {-Carotene } \\
\text { (CRT) }\end{array}$ & - & $\begin{array}{l}\text { DEE: } 46 \% \text {, DLC: } 9.3 \% \\
\text { - Hydrodynamic radius: } \\
70-100 \mathrm{~nm} \text {. } \\
\text { CS-BSA NPs were pre- } \\
\text { pared by electrostatic } \\
\text { adsorption, followed by } \\
\text { thermal treatment }\end{array}$ & [83] \\
\hline
\end{tabular}

†Particle diameters are approximate; BSA, bovine serum albumin; Egg albumin = ovalbumin; DEE, drug entrapment efficiency (approximate); DLC, drug-loading capacity (approximate); PEG, polyethylene glycol; ZP, zeta potential.

An initial burst $(20 \%$ in $1 \mathrm{~h})$, followed by $80 \%$ of the cumulative slow release of gemcitabine was observed up to $90 \mathrm{~h}$. Evaluation of the nanoparticles on human pancreatic cancer cell line BxPC-3 in vitro found equivalent cytotoxicity of gemcitabine, gemcitabine-C14, and gemcitabine-HSA-NPs. An excellent inhibitory effect on tumor growth (BxPC-3 cell line) was found, with the lowest toxicity for gemcitabineHSA-NPs [85].

Gambogic acid (GmA) is a well-known chemotherapeutic agent for lung cancer treatment and exhibits poor water solubility and low chemical stability. Zhang et al. [86] developed HSA nanoparticles loaded with GmA with increased solubility, low toxicity, and enhanced antitumor efficacy using nab technology. The spherical GmA-HSA nanoparticles of $135 \mathrm{~nm}$ diameter and zeta potential of $-21.81 \mathrm{mV}$ exhibited GmA loading of $11 \%$ and entrapment efficiency of $99 \%$. No increase in the size of the prepared nanoparticles was observed up to 200 -fold dilutions with $5 \%$ HSA solution. Furthermore, they exhibited physical stability during circulation in blood. No shrinkage, collapse, or increase in particle size of 


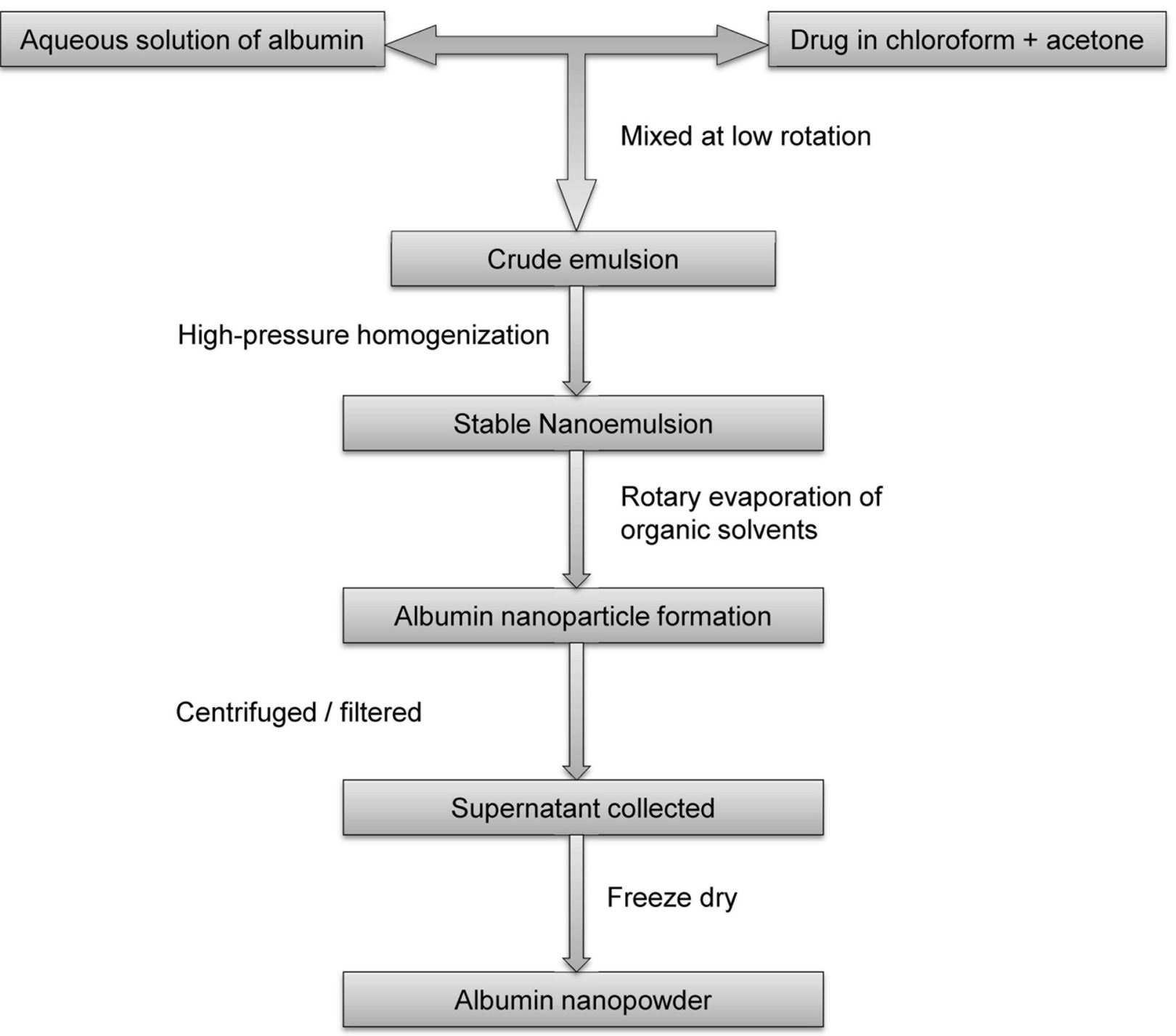

Figure 8. Preparation of drug-loaded albumin nanoparticles using nab technology.

the freeze-dried nanoparticles was noticed after storage for 12 months, and the GmA-HSA nanoparticles could be reconstituted in saline or normal water. An aqueous suspension was stable for $>8$ weeks at $4{ }^{\circ} \mathrm{C}$ and $25{ }^{\circ} \mathrm{C}$ [86]. An initial burst (due to surface $\mathrm{GmA}$ ), followed by a slow release of $70 \%$ GmA, was observed at $\mathrm{pH} 7.4$ with PBS and $40 \%$ ethanol. The hydrophobic interaction of HSA with GA increases the release time of GmA from the NPs. GmA-HSA nanoparticles showed enhanced antitumor efficacy in A549-bearing mice with low toxicity and no significant tail necrosis during treatment [86].

Considering the exclusive overexpression of asialoglycoprotein receptors (ASGPRs) in the hepatocytes of welldifferentiated hepatocellular carcinoma (HCC), dual drug (paclitaxel and doxorubicin)-loaded lactobionic acid-modified
BSA (Lac-BSA) nanoparticles of $148 \mathrm{~nm}$ diameter with high surface charge $(-54.1 \mathrm{mV})$ have been prepared [87]. Because lactose exhibits high receptor affinity toward the ASGPR ligand, the prepared nanoparticles can be used for the selective targeting of the liver. Confocal laser scanning microscopy and flow cytometry demonstrated that doxorubicin-paclitaxelLac-BSA nanoparticles exhibit superior cellular uptake by Hep G2-containing cells. Slow release of $84 \%$ of paclitaxel and $73 \%$ of doxorubicin was observed from the nanoparticles in PBS containing Tween 80 at $37{ }^{\circ} \mathrm{C}$. The absence of a significant burst release reduces the toxicity of paclitaxel and doxorubicin [87]. Table 5 shows the characterization, target indications, drug release pattern, and cytotoxicity of albumin and functionalized albumin nanoparticles prepared by nab technology. 
Table 5. Characterization, target indications, drug release pattern, and cytotoxicity of albumin and functionalized albumin nanoparticles prepared by nab technology

\begin{tabular}{|c|c|c|c|c|c|c|}
\hline Albumin used & Organic phase & $\begin{array}{l}\text { Functionalizing or } \\
\text { conjugating agent }\end{array}$ & $\begin{array}{l}\text { Drug or } \\
\text { antioxidant loaded }\end{array}$ & $\begin{array}{l}\text { Target } \\
\text { indication }\end{array}$ & Outcome or application & Reference \\
\hline HSA in water & $\begin{array}{l}\text { Chloroform + } \\
\text { ethanol mixture }\end{array}$ & - & Tacrolimus (TAC) & $\begin{array}{l}\text { Rheumatoid } \\
\text { arthritis }\end{array}$ & $\begin{array}{l}\text { Particle diameter: } 186 \mathrm{~nm} \text {, } \\
\text { ZP: }-30.5 \mathrm{mV}, \mathrm{DEE}: 79 \% \text {, } \\
\text { DLC: } 1.5 \% \\
\text { - Increased solubility ( } 46 \\
\text { times) in water than free TAC } \\
\text { - } 94 \% \text { release of TAC in } 24 \mathrm{~h} \\
\text { - Excellent tumor targeting } \\
\text { and antiarthritic activity }\end{array}$ & [84] \\
\hline HSA in water & Chloroform & - & Gem-C14 & $\begin{array}{l}\text { Pancreatic } \\
\text { cancer }\end{array}$ & $\begin{array}{l}\text { Particle diameter: } 150 \mathrm{~nm} \text {, } \\
\text { ZP: }-10.2 \mathrm{mV}, \mathrm{DEE}: 83 \% \text {, } \\
\text { DLC: } 10 \% \\
\text { - } 82 \% \text { of slow GEM release } \\
\text { in } 90 \mathrm{~h} \\
\text { - An excellent inhibitory } \\
\text { effect on tumor growth in } \\
\text { the BxPc-3 cell line }\end{array}$ & [85] \\
\hline HSA in water & $\begin{array}{l}\text { Mixed organic } \\
\text { phase }\end{array}$ & - & $\begin{array}{l}\text { Gambogic acid } \\
(\mathrm{GmA})\end{array}$ & Lung cancer & $\begin{array}{l}\text { Particle diameter: } 135 \mathrm{~nm} \text {, } \\
\text { ZP: }-21.81 \mathrm{mV}, \mathrm{DEE}: 99.3 \% \text {, } \\
\text { DLC: } 11 \% \\
\text { - Nanopowder is stable for } \\
\text { up to } 12 \text { months } \\
\text { - } 69 \% \text { of slow GmA release } \\
\text { in } 72 \mathrm{~h} \\
\text { - Increased TGI than GmA } \\
\text { and GmA-Arg in A549- } \\
\text { bearing mice. }\end{array}$ & [86] \\
\hline BSA in water & $\begin{array}{l}\text { Chloroform + } \\
\text { ethanol mixture }\end{array}$ & Lactobionic acid & $\begin{array}{l}\text { Doxorubicin (DOX) } \\
\text { and paclitaxel (PTX) }\end{array}$ & Liver cancer & $\begin{array}{l}\text { Particle diameter: } 148 \mathrm{~nm} \text {, } \\
\text { ZP: }-54.1 \mathrm{mV} \\
\text { - } 84 \% \text { PAC and } 73 \% \text { DOX } \\
\text { release in } 24 \mathrm{~h} \\
\text { - } \quad \text { Lactose residue exhibits } \\
\text { high receptor affinity } \\
\text { toward ASGPR } \\
\text { - } 62 \% \text { internalization in } \\
\text { HepG2 cells } \\
\text { - Improved therapeutic effi- } \\
\text { cacy against HepG2 cells }\end{array}$ & [87] \\
\hline
\end{tabular}

†Particle diameters are approximate; ASGPR, asialoglycoprotein receptor; BSA, bovine serum albumin; DEE, drug entrapment efficiency (approximate); DLC, drug-loading capacity (approximate); Gem-C14, 4-N-myristoyl-gemcitabine; HSA, human serum albumin; TGl, tumor growth inhibition rate; $Z$, zeta potential.

\section{Self-assembly}

The self-assembly strategy commonly involves reducing the number of primary amine groups on the protein surface by covalent conjugations, reduction in disulfide bonds, and addition of lipophilic drugs, which could increase the hydrophobicity of albumin and drive molecules to self-assemble to form nanoparticles [88, 89]. Figure 9 shows a schematic representation of the self-assembly process for production of albuminbased nanoparticles.
To overcome the toxicity of chemical cross-linking agents, paclitaxel-loaded HSA nanoparticles (paclitaxel-HSANPs) have been synthesized using a self-assembly method [90]. The method involves adding $\beta$-mercaptoethanol to an aqueous solution of HSA to expose hydrophobic domains by unfolding the HSA through disulfide bond cleavage. A slightly blue-colored paclitaxel-HSA-NP solution was obtained after adding paclitaxel. After removing $\beta$-mercaptoethanol, the resultant nanoparticles were freeze-dried. The self-assembled nanoparticles with diameter of $120 \mathrm{~nm}$ and surface charges 


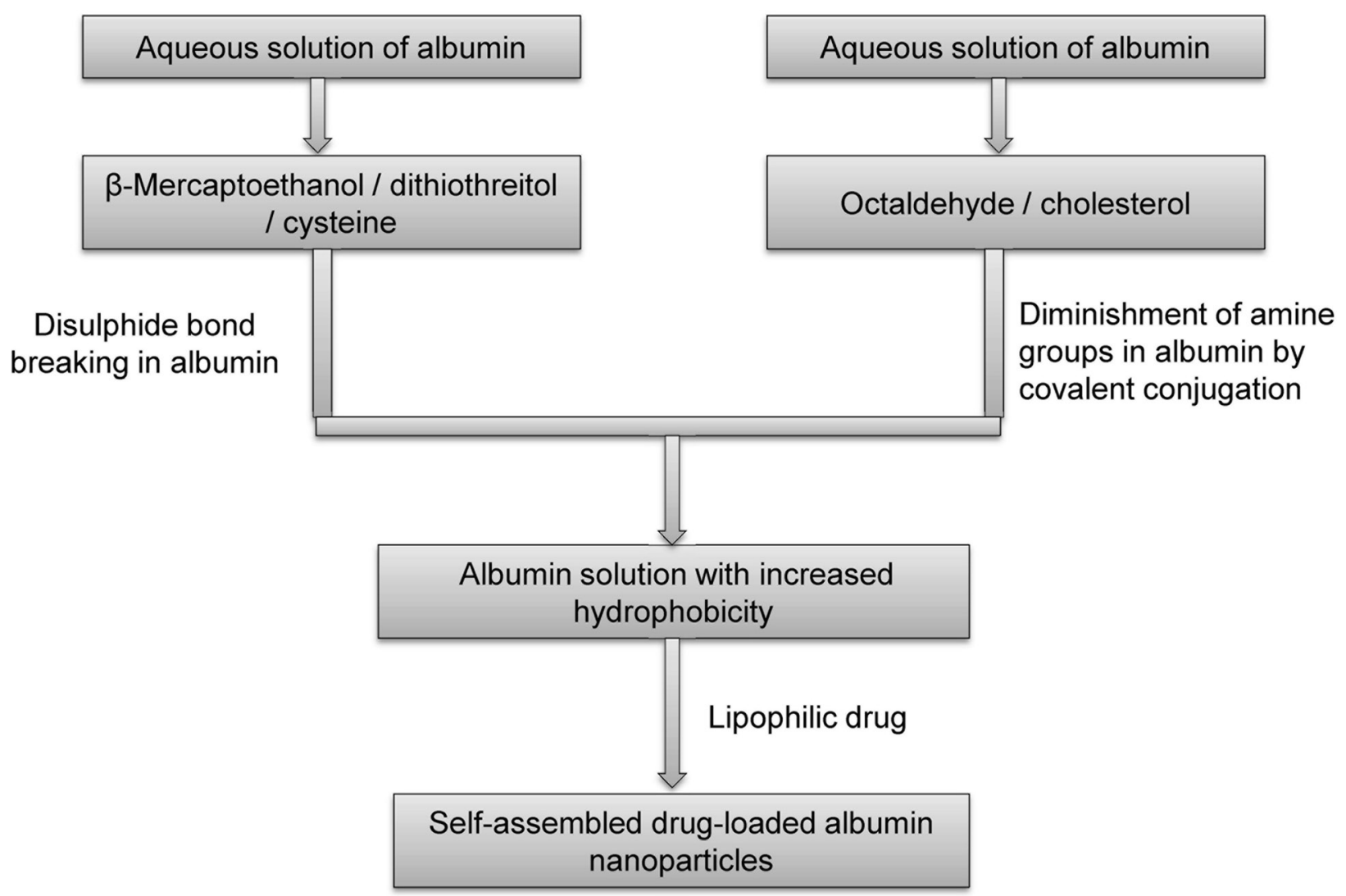

Figure 9. Preparation of drug-loaded albumin nanoparticles using self-assembly.

of -20 to $-30 \mathrm{mV}$ showed $>20 \%$ loading with up to $100 \%$ entrapment of paclitaxel. The prepared paclitaxel-HSA-NPs displayed stability and enhanced cytotoxicity toward MCF-7 and A549 cell lines. Longer mice survival with slower tumor growth was observed in H22 tumor-bearing mice when treated with the prepared nanoparticles, compared with free paclitaxel [90].

Wang et al. [91] developed a self-assembled protein nanocarrier for lipophilic drugs by breaking disulfide bonds using dithiothreitol (DTT) as a reducing agent. Curcuminloaded HSA nanoparticles (curcumin-HSA-NPs) were prepared by adding curcumin to DTT-denatured HSA at $25^{\circ} \mathrm{C}$. The nonspecific adsorption of curcumin leads to the formation of curcumin-HSA-NPs of $100 \mathrm{~nm}$ diameter with irregular surface morphology. The nanoparticles exhibit curcumin loading of $4 \%$ and entrapment efficiency of $92 \%$ at $25{ }^{\circ} \mathrm{C}$ [91]. An initial $45 \%$ burst, followed by up to a $100 \%$ release of curcumin from nanoparticles in $>24 \mathrm{~h}$ was observed. MCF-7 cell lines show an enhanced accumulation of nanoparticles in the cytoplasm of tumor cells in vitro. After intravenous injection of CUR-HSA-NPs into $\mathrm{H}-22$-bearing mice, accumulation of nanoparticles was found at tumor sites in vivo after $1 \mathrm{~h}$, which reached a peak level after $28 \mathrm{~h}$ [91].

The self-assembly strategy was adopted for the production of paclitaxel-loaded cholesterol-conjugated albumin nanoparticles (paclitaxel-Chol-BSA) [92]. The cholesterolalbumin conjugate was prepared using $N, N$-disuccinimidyl carbonate as a coupling agent. The self-assembled nanoparticles of $146 \mathrm{~nm}$ diameter and $-20 \mathrm{mV}$ surface charge exhibited higher colloidal stability than paclitaxel-BSA nanoparticles. The addition of cholesterol to BSA increases the hydrophobic properties of the nanoparticles such that they show very high loading capacity (38\%) and entrapment efficiency (95\%) for paclitaxel [92]. B16F10 and MCF-7 cancer cell lines treated with paclitaxel-Chol-BSA nanoparticles exhibited increased cellular uptake and cytotoxicity in vitro than other paclitaxelBSA formulations. The paclitaxel-Chol-BSA nanoparticles show a much slower and prolonged release of paclitaxel and enhanced antitumor efficacy in tumor-bearing mice than other paclitaxel-BSA nanoformulations [92]. Table 6 shows the characterization, target indications, drug release pattern, and cytotoxicity of albumin and functionalized albumin nanoparticles prepared by self-assembly. 
Table 6. Characterization, target indications, drug release pattern, and cytotoxicity of albumin and functionalized albumin nanoparticles prepared by self-assembly

\begin{tabular}{|c|c|c|c|c|c|c|}
\hline Albumin used & $\begin{array}{l}\text { Conjugating or } \\
\text { disulfide reducing } \\
\text { agent }\end{array}$ & $\begin{array}{l}\text { Drug or } \\
\text { antioxidant loaded }\end{array}$ & $\begin{array}{l}\text { Self-assembly } \\
\text { strategy }\end{array}$ & $\begin{array}{l}\text { Target } \\
\text { indication }\end{array}$ & Outcome or applications & Reference \\
\hline HSA & $\begin{array}{l}\beta \text {-Mercaptoethanol } \\
(\beta-M E)\end{array}$ & Paclitaxel (PTX) & $\begin{array}{l}\text { Disulfide bond } \\
\text { breaking }\end{array}$ & $\begin{array}{l}\text { Breast cancer } \\
\text { (MCF- } 7 \text { and } \\
\text { A549 cell } \\
\text { lines) }\end{array}$ & $\begin{array}{l}\text { Particle diameter: } \\
120 \mathrm{~nm}, \mathrm{ZP}:-30.0 \mathrm{mV} \text {, } \\
\text { DEE: } 100 \%, \mathrm{DLC}: 20 \% \\
\text { More stability and } \\
\text { enhanced cytotoxicity } \\
\text { toward MCF-7 and A549 } \\
\text { cells } \\
\text { - Longer survival of } \\
\text { H22-bearing mice }\end{array}$ & [90] \\
\hline HSA & Dithiothreitol (DTT) & Curcumin (CUR) & $\begin{array}{l}\text { Disulfide bond } \\
\text { breaking }\end{array}$ & $\begin{array}{l}\mathrm{H} 22 \text { tumor- } \\
\text { bearing mice }\end{array}$ & $\begin{array}{l}\text { Particle diameter: } 100 \mathrm{~nm} \text {, } \\
\text { DEE: } 92 \%, \text { DLC: } 4 \% \\
\text { Initial } 45 \% \text { burst, follo- } \\
\text { wed by } 100 \% \text { release of } \\
\text { CUR in }>24 \mathrm{~h} \\
\text { - Enhanced accumulation } \\
\text { of NPs in the cytoplasm } \\
\text { of tumor cells } \\
\text { - Accumulation of NPs in } \\
\text { H22-bearing mice (at } \\
\text { tumor sites), reaches the } \\
\text { peak level after } 28 \mathrm{~h}\end{array}$ & [91] \\
\hline BSA & Cholesterol & Paclitaxel (PTX) & $\begin{array}{l}\text { Covalent con- } \\
\text { jugate }\end{array}$ & $\begin{array}{l}\text { Breast cancer } \\
\text { (B16F10 and } \\
\text { MCF-7 cell } \\
\text { lines) }\end{array}$ & $\begin{array}{l}\text { Particle diameter: } \\
146 \mathrm{~nm}, \mathrm{ZP}:-20.0 \mathrm{mV} \text {, } \\
\text { DEE: } 95 \%, \mathrm{DLC}: 38 \% \\
\text { - Enhanced cellular uptake } \\
\text { and cytotoxicity toward } \\
\text { B16F10 and MCF-7 } \\
\text { cancer cell lines } \\
\text { - Much slower and prolon- } \\
\text { ged release of PTX } \\
\text { - Longer survival of tumor- } \\
\text { bearing mine }\end{array}$ & [92] \\
\hline BSA & Aptamer AS1411 & Doxorubicin (DOX) & $\begin{array}{l}\text { Hydrophobic } \\
\text { drug interac- } \\
\text { tion }\end{array}$ & $\begin{array}{l}\text { Breast cancer } \\
\text { (MCF-7 cell } \\
\text { line) }\end{array}$ & $\begin{array}{l}\text { Particle diameter: } \\
163 \mathrm{~nm}, \mathrm{ZP}:-20.7 \mathrm{mV} \\
\text { DEE: 78\%, DLC: } 4.4 \% \\
\text { Aptamer AS1411: for } \\
\text { specific targeting as } \\
\text { receptors are overex- } \\
\text { pressed on tumor cells } \\
\text { Increased cytotoxicity } \\
\text { due to enhanced cellular } \\
\text { uptake in MCF-7 cells }\end{array}$ & [93] \\
\hline BSA & - & Curcumin (CUR) & $\begin{array}{l}\text { Hydrophobic } \\
\text { drug interac- } \\
\text { tion }\end{array}$ & - & $\begin{array}{l}\text { Particle diameter: } 110 \mathrm{~nm} \text {, } \\
\text { DEE: } 89 \% \text {, DLC: } 7 \% \\
\text { lonic strength is the key } \\
\text { parameter for nanopar- } \\
\text { ticle production } \\
\text { - Strong antioxidant } \\
\text { activity and effective and } \\
\text { neuroprotective effects } \\
\text { on neuronal HT22 cells }\end{array}$ & [94] \\
\hline
\end{tabular}


Table 6. Continued

\begin{tabular}{|c|c|c|c|c|c|c|}
\hline Albumin used & $\begin{array}{l}\text { Conjugating or } \\
\text { disulfide reducing } \\
\text { agent }\end{array}$ & $\begin{array}{l}\text { Drug or } \\
\text { antioxidant loaded }\end{array}$ & $\begin{array}{l}\text { Self-assembly } \\
\text { strategy }\end{array}$ & $\begin{array}{l}\text { Target } \\
\text { indication }\end{array}$ & Outcome or applications & Reference \\
\hline HSA & PEG & Paclitaxel (PTX) & $\begin{array}{l}\text { Covalent } \\
\text { conjugation } \\
\text { (film casting } \\
\text { method) }\end{array}$ & $\begin{array}{l}\text { Human breast } \\
\text { cancer cell } \\
\text { lines (SK-BR-3, } \\
\text { MDA-MB-453 } \\
\text { and MCF-7), } \\
\text { SK-BR-3 } \\
\text { tumor-bea- } \\
\text { ring mice }\end{array}$ & $\begin{array}{l}\text { Particle diameter: } \\
280 \mathrm{~nm}, \mathrm{DEE}: 86 \%, \mathrm{DLC} \\
8.7 \% \\
\text {. } \\
\text { Enhanced solubility and } \\
\text { sustained release of PTX } \\
\text { - } \quad \text { Prolonged and systemic } \\
\text { circulation of nanopar- } \\
\text { ticles after intravenous } \\
\text { injection } \\
\text { - Higher cytotoxicity in } \\
\text { human breast cancer cell } \\
\text { lines (SK-BR-3, MDA-MB- } \\
453, \text { and MCF-7) }\end{array}$ & [95] \\
\hline
\end{tabular}

†Particle diameters are approximate; BSA, bovine serum albumin; DEE, drug entrapment efficiency (approximate); DLC, drug-loading capacity (approximate); HSA, human serum albumin; NPs, nanoparticles; PEG, polyethylene glycol; ZP, zeta potential.

\section{Nanospray drying}

Developing size- and shape-controlled reproducible nanoencapsulation technology for targeted drug delivery systems remains a challenge. Due to its simplicity, reproducibility, low operating cost, and ease of scale-up capability, spray-drying technology has attracted the attention of the pharmaceutical sector for encapsulation of pharmaceuticals to develop drugencapsulated nanopowder with controlled drug release properties [96-99]. Spray drying is an excellent method by which to produce drug-loaded albumin nanoparticles with low risk of degradation as this method can be used with mild temperatures and is less dependent on the solubility of albumin and the drug [97]. The nanoparticles produced by spray drying exhibit a narrow size distribution, high encapsulation efficiency, and extended shelf life [97].

A typical nanospray dryer (B-90; Büchi Labortechnik) produces powdered particles in the nano range and includes 3 steps (Figure 10). The first generates droplets by atomizing the supplied solutions of protein and drug. A vibrating mesh technology to generate fine droplets includes the use of piezoelectric actuator-driven thin spray meshes containing a large number of uniform laser-drilled holes. On the application of ultrasonic frequency $(80-140 \mathrm{kHz})$, the holes of the vibrating mesh are loaded with fluid, and the fluid is pushed through the mesh to produce uniform droplets with a very narrow size distribution [97]. The droplets are sprayed into a drying chamber in a second step where inert nitrogen and a small amount of carbon dioxide are used for drying. A laminar flow of gas is maintained to dry the sprayed droplets gently [97]. The third step uses a high voltage $(15 \mathrm{kV})$ to negatively charge the dried particles and collect them electrostatically with very high efficiency [3].

Despite the high temperature of the drying gas, the spraydrying process is suitable for heat-sensitive materials such as proteins, the cooling effect of the evaporating solvent keeping the droplet temperature relatively low. Lee et al. [98] used a B-90 spray dryer to produce spherical BSA nanoparticles with a median diameter of $460 \mathrm{~nm}$. A B-90 nanospray dryer was used to prepare respirable $\beta$-galactosidase powder in the particle diameter range of $1-5 \mu \mathrm{m}$ without loss of enzyme activity using trehalose as a stabilizer [100].

\section{Conclusion}

Nanocarrier systems have proven themselves as an important asset to the pharmaceutical industry. Nanocarriers can encapsulate active drug molecules and increase the latter's therapeutic index through their target-specific action and protect the drug molecule from undesirable metabolic reactions and biodegradations. The high water solubility, biodegradability, low toxicity, and ease of purification of albumin make it a classic candidate for nanoparticle preparation and a versatile drug carrier that can be delivered easily by injection.

The various methods adopted to prepare albumin nanoparticles have their own advantages and disadvantages. Emulsification, the most established technique to produce albumin nanoparticles, involves the use and subsequent removal of organic solvents, oily residues, and surfactants. For heat-sensitive drugs, the use of toxic chemical crosslinking agents to stabilize nanoparticles creates problems. 


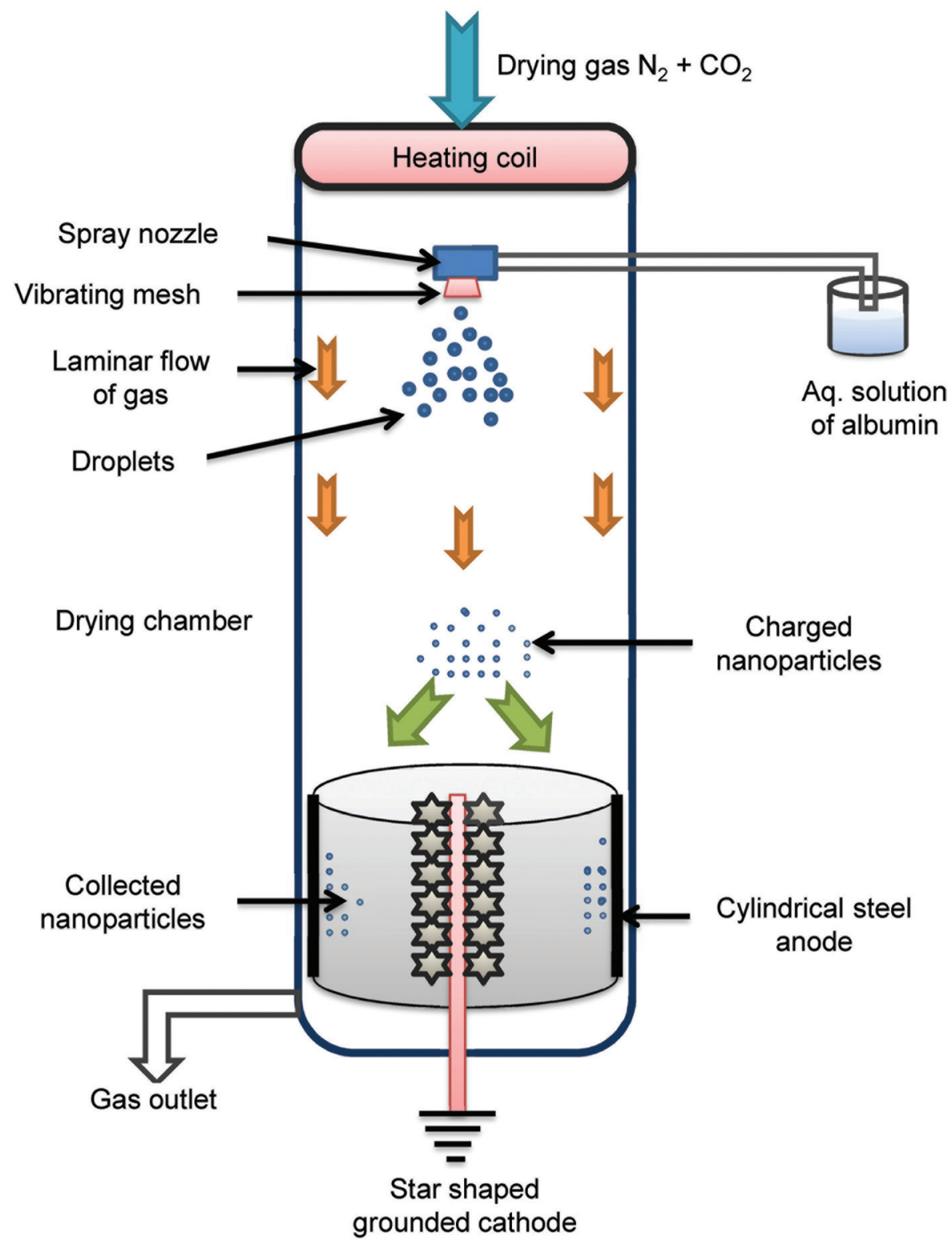

Figure 10. Spray-drying process for the preparation of albumin nanoparticles.

Desolvation, an alternative to emulsification, is a highly reproducible process for controlling the size and shape of albumin nanoparticles. A major concern with the process is the use of toxic chemical cross-linkers to stabilize the nanoparticles formed after denaturation of albumin. Thermal gelation to produce protein nanoparticles is not suitable for heat-sensitive drugs. Nab technology is ideal to encapsulate lipophilic anticancer drugs in the protein matrix for their safe and effective intravenous delivery. The process does not require surfactants or chemical cross-linkers. Selfassembly provides a high degree of lipophilic drug loading by increasing the hydrophobicity of albumin via disulfide bond reduction or decreasing the number of amine groups, although the process may require toxic chemicals to break the disulfide bonds. Nanospray drying is an excellent scalable process to continuously produce dry drug-loaded albumin nanoparticles in a single step. The nanoparticles prepared by the various methods show high drug-loading and -entrapment efficiencies, and the solubility of poorly water-soluble drugs is increased. Nanoparticles exhibit slow and sustained release of drugs as an advantage over free drugs. The introduction of target-specific ligands to albumin nanoparticles increases their uptake by a variety of cancer cells as a result of the overexpression of ligand receptors on the cancer cells. The enhanced accumulation of drug-loaded albumin nanoparticles to tumor sites increases their antitumor efficacy toward various 
cancer cells, and the slow and sustained release of drug from the nanoparticles reduces their side effects and increases the survival rate of experimental animals.

Author contributions: SA and PA conceived and designed the review. Both authors contributed substantially to review of the literature, its analysis, and interpretation. Both authors contributed to drafting and critical revision of the manuscript. Both authors approved the final version submitted for publication and take responsibility for the statements made in the published article.

Conflicts of interest statement: The authors have each completed and submitted an International Committee of Medical Journal Editors Uniform Disclosure Form for Potential Conflicts of Interest. None of the authors has any potential or actual conflict of interest to disclose in relation to the published article. No financial or nonfinancial benefits have been or will be received from any party related directly or indirectly to the subject of this article.

Data sharing statement: No data sets were generated or analyzed during the present study. The present review was based on the references cited.

\section{References}

[1] Deborah E, Citrin MD. Recent developments in radiotherapy. N Eng J Med. 2017; 377:1065-75.

[2] Jha S, Mathur P, Ramteke S, Jain NK. Pharmaceutical potential of quantum dots. Artif Cells Nanomed Biotechnol. 2018; 46:57-65.

[3] Elzoghby AO, Samy WM, Elgindt NA. Albumin-based nanoparticles as potential controlled drug delivery systems. J Control Release. 2012; 157:168-82.

[4] Ziarani M, Malmir M, Lashgari N, Badiei A. The role of hollow magnetic nanoparticles in drug delivery. RSC Adv. 2019; 9:5094-106.

[5] Anderson SD, Gwenin VV, Gwenin CD. Magnetic functionalized nanoparticles for biomedical, drug delivery and imaging applications. Nanoscale Res Lett. 2019; 14:188. doi: 10.1186/s11671019-3019-6

[6] Vangijzegem T, Stanicki D, Laurent S. Magnetic iron oxide nanoparticles for drug delivery: applications and characteristics. Expert Opin Drug Deliv. 2019; 16:69-78.

[7] Cordero LB, Alkorta I, Arana L. Application of solid lipid nanoparticles to improve the efficiency of anticancer drugs. Nanomaterials. 2019; 9:474. doi: 10.3390/nano9030474

[8] Hosseini SM, Abbasalipourkabir R, Jalilian FA, Asl SS, Farmany A, Roshanaei G, Arabestani MR. Doxycycline-encapsulated solid lipid nanoparticles as promising tool against Brucella melitensis enclosed in macrophage: a pharmacodynamics study on J774A.1 cell line. Antimicrob Resist Infect Control. 2019; 8:62. doi: 10.1186/s13756019-0504-8
[9] Mishra V, Bansal KK, Verma A, Yadav N, Thakur S, Sudhakar K, Rosenholm JM. Solid lipid nanoparticles: emerging colloidal nano drug delivery systems. Pharmaceutics. 2018; 10:191. doi: 10.3390/ pharmaceutics 10040191

[10] Naeem S, Viswanathan G, Misran M. Liposomes as colloidal nanovehicles: on the road to success in intravenous drug delivery. Rev Chem Eng. 2017; 34:365-83.

[11] Ahmad N, Ahmad R, Alam MA, Ahmad FJ. Enhancement of oral bioavailability of doxorubicin through surface modified biodegradable polymeric nanoparticles. Chem Cent J. 2018; 12:65. doi: 10.1186/s13065-018-0434-1

[12] Jin M, Jin G, Kang L, Chen L, Gao Z, Huang W. Smart polymeric nanoparticles with $\mathrm{pH}$-responsive and PEG-detachable properties for co-delivering paclitaxel and survivin siRNA to enhance antitumor outcomes. Int J Nanomed. 2018; 13:2405-23.

[13] Singh P, Pandit S, Mokkapati VRSS, Garg A, Ravikumar V, Mijakovic I. Gold nanoparticles in diagnostics and therapeutics for human cancer. Int J Mol Sci. 2018; 19:1979. doi: 10.3390/ ijms19071979

[14] Li J, Wang X, Zhang T, Wang C, Huang Z, Luo X, Deng Y. A review on phospholipids and their main applications in drug delivery systems. Asian J Pharm Sci. 2015; 10:81-98.

[15] Yu G, Ning Q, Mo Z, Tang S. Intelligent polymeric micelles for multidrug co-delivery and cancer therapy. Artif Cells Nanomed Biotechnol. 2019; 47:1476-87.

[16] Martínez-Lopez AL, Pangua C, Reboredo C, Campión R, Morales-Gracia J, Irache JM. Protein-based nanoparticles for drug delivery purposes. Int J Pharma. 2020; 581:119289. doi: 10.1016/j. ijpharm.2020.119289

[17] Okamoto Y, Taguchi K, Imoto S, Chuang VTG, Yamasaki K, Otagiri M. Cell uptake and anti-tumor effect of liposomes containing encapsulated paclitaxel-bound albumin against breast cancer cells in 2D and 3D cultured models. J Drug Deliv Sci Technol. 2020; 55:101381. doi: 10.1016/j.jddst.2019.101381

[18] Langer K, Balthasar S, Vogel V, Dinauer H, Briesen H, Schubert D. Optimization of the preparation process for human serum albumin (HSA) nanoparticles. Int J Pharm. 2003; 275:169-80.

[19] Lomis N, Westfall S, Farahdel L, Mathotra M, Tim DS, Prakash S. Human serum nanoparticles for use in cancer drug delivery: process optimization and in vitro characterization. Nanomaterials. 2016; 6:116. doi: 10.3390/nano6060116

[20] Haeri HH, Schunk B, Tomaszewski J, Schimm H, Gelos MJ, Hinderberger D. Fatty acid binding to human serum albumin in blood serum characterized by EPR spectroscopy. ChemistryOpen. 2019; 8:650-56.

[21] Rabah SA, Gowan IL, Pagnin M, Osman N, Richardson SJ. Thyroid hormone distributor proteins during development in vertebrates. Front Endocrinol. 2019; 10:506. doi: 10.3389/fendo.2019.00506

[22] Pontremoli C, Barbero N, Viscardi G, Visentin SJ. Insight into the interaction of inhaled corticosteroids with human serum albumin: a spectroscopic-based study. Pharm Anal. 2018; 8:37-44.

[23] Seijsing J, Sobieraj AM, Keller N, Shen Y, Zinkernagel AS, Loessner MJ, Schmelcher M. Improved biodistribution and extended serum half-life of a bacteriophage endolysin by albumin binding domain fusion. Front Microbiol. 2018; 9:2927. doi: 10.3389/ fmicb.2018.02927

[24] Michelis R, Sela S, Zeitun T, Geron R, Kristal B. Unexpected normal colloid osmotic pressure in clinical states with low serum 
albumin. PLoS ONE. 2016; 11:e0159839. doi: 10.1371/journal. pone.0159839

[25] Coverdale JPC, Barnett JP, Adamu AH, Griffiths EJ, Stewart AJ, Blindauer CA. A metalloproteomic analysis of interactions between plasma proteins and zinc: elevated fatty acid levels affect zinc distribution. Metallomics. 2019; 11:1805-19.

[26] Meloun B, Moravek L, Kostka V. Complete amino acid sequence of human serum albumin. FEBS Lett. 1975; 58:134-7.

[27] Usoltsev D, Sitnikova V, Kajava A, Uspenskaya M. Systematic FTIR spectroscopy study of the secondary structure changes in human serum albumin under various denaturation conditions. Biomolecules. 2019; 9:359. doi: 10.3390/biom9080359

[28] Majorek KA, Porebski PJ, Dayal A, Zimmerman MD, Jablonska $\mathrm{K}$, Stewart AJ, et al. Structural and immunologic characterization of bovine, horse, and rabbit serum albumins. Mol Immunol. 2012; 52:174-82.

[29] Huang BX, Kim H-Y, Dass CJ. Probing three-dimensional structure of bovine serum albumin by chemical cross-linking and mass spectrometry. J Am Soc Mass Spectrom. 2004; 15:1237-47.

[30] Kovács AN, Varga N, Gombár G, Hornok V, Csapó E. Novel feasibilities for preparation of serum albumin-based core-shell nanoparticles in flow conditions. J Flow Chem. 2020. doi: 10.1007/ s41981-020-00088-4

[31] Li FQ, Su H, Wang J, Liu JY, Zhu QG, Fei YB, et al. Preparation and characterization of sodium ferulate entrapped bovine serum albumin nanoparticles for liver targeting. Int J Pharm. 2008; 349:274-82.

[32] Jithan AV, Madhavi K, Madhavi M, Prabhakar K. Preparation and characterization of albumin nanoparticles encapsulating curcumin intended for the treatment of breast cancer. Int J Pharm Investig. 2011; 1:119-25.

[33] Uhle ESB, Costa BC, Ximenes VF, Filho PNL. Synthetic nanoparticles of bovine serum albumin with entrapped salicylic acid. Nanotechnol Sci Appl. 2017; 10:11-21.

[34] Amighi F, Emam-Djomeh Z, Labbaf-Mazraeh-Shahi M. Effect of different cross-linking agents on the preparation of bovine serum albumin nanoparticles. J Iran Chem Soc. 2020; 17:1223-35.

[35] Esfahlan AJ, Dastmalchi S, Davaran S. A simple desolvation method for the rapid preparation of albumin nanoparticles. Int J Biol Macromol. 2016; 91:703-9.

[36] Galisteo-González F, Molina-Bolívar JA. Systematic study on the preparation of BSA nanoparticles. Colloids Surf B Biointerfaces. 2014; 123:286-92.

[37] Rohiwal SS, Pawar SH. Synthesis and characterization of bovine serum albumin nanoparticles as a drug delivery vehicle. Int J Pharm Bio Sci. 2014; 5(4):(B)51-7.

[38] Paik S-Y-R, Nguyen HH, Ryu J, Che J-H, Kang TS, Lee JK, et al. Robust size control of bovine serum albumin (BSA) nanoparticles by intermittent addition of a desolvating agent and the particle formation mechanism. Food Chem. 2013; 141:695-701.

[39] Yedomon B, Fessi H, Charcosset C. Preparation of bovine serum albumin (BSA) nanoparticles using a membrane contactor: a new tool for large scale production. Eur J Pharma Biopharm. 2013; 85:398-405.

[40] Prajapati A, Srivastava A, Pramanik P. A simple and reproducible method for production of protein nanoparticles at biological $\mathrm{pH}$ using egg white. Biointerface Res App Chem. 2019; 9:3783-9.

[41] Lamichhane S, Lee S. Albumin nanoscience: homing nanotechnology enabling targeted drug delivery and therapy. Arch Pharm Res. 2020; 43:118-33.
[42] Karami K, Jamshidian N, Hajiaghasi A, Amirghofran Z. BSA nanoparticles as controlled release carriers for isophethalaldoxime palladacycle complex; synthesis, characterization, in vitro evaluation, cytotoxicity and release kinetics analysis. New J Chem. 2020. doi: 10.1039/c9nj05847h

[43] Dreis S, Rothweiler F, Michaelis M, Cinatl J Jr, Kreuter J, Langer K. Preparation, characterisation and maintenance of drug efficacy of doxorubicin-loaded human serum albumin (HSA) nanoparticles. Int J Pharm. 2007; 341:207-14.

[44] Singh P, Singh H, Castro-Aceituno VC, Ahn S, Kim YJ, Yang DC. Bovine serum albumin as nanocarrier for the efficient delivery of ginsenoside compound K: preparation, physiochemical characterizations and in vitro biological studies. RSC Adv. 2017; 7:15397-407.

[45] Fernandez M, Javaid F, Chudasama V. Advances in targeting the folate receptor in the treatment/imaging of cancers. Chem Sci. 2018; 9:790-810.

[46] Martínez A, Olmo R, Iglesias I, Teijón JM, Blanco MD. Folatetargeted nanoparticles based on albumin and albumin/alginate mixtures as controlled release systems of tamoxifen: synthesis and in vitro characterization. Pharm Res. 2014; 31:182-93.

[47] Qi L, Guo Y, Luan J, Zhang D, Zhao Z, Luan Y. Folate-modified bexarotene-loaded bovine serum albumin nanoparticles as a promising tumor targeting delivery system. J Mater Chem B. 2014; 2:8361-71.

[48] Chen D, Tang Q, Xue W, Xiang J, Zhang L, Wang X. The preparation and characterization of folate-conjugated human serum albumin magnetic cisplatin nanoparticles. J Biomed Res. $2010 ; 24: 26-32$

[49] Nosrati H, Abbasi R, Charmi J, Rakhshbahar A, Aliakbarzadeh F, Danafar H, Davaran S. Folic acid conjugated bovine serum albumin: An efficient smart and tumor targeted biomacromolecule for inhibition folate receptor positive cancer cells. Int J Biol Macromol. 2018; 117:1125-32.

[50] Mohammad-Beigi H, Shojaosadati SA, Morshedi D, Arpanaei A, Marvian AT. Preparation and in vitro characterization of gallic acid loaded human serum albumin nanoparticles. J Nanopart Res. 2015; 17:167. doi: 10.1007/s11051-015-2978-5

[51] Abbasi S, Paul A, Shao W, Prakash S. Cationic albumin nanoparticles for enhanced drug delivery to treat breast cancer: preparation and in vitro assessment. J Drug Deliv. 2012; 2012:686108. doi: $10.1155 / 2012 / 686108$

[52] Kouchakzadeha H, Shojaosadati SA, Shokri F. Efficient loading and entrapment of tamoxifen in human serum albumin based nanoparticulate delivery system by a modified desolvation technique. Chem Eng Res Des. 2014; 92:1681-92.

[53] Li C, Zhang D, Guo H, Hao L, Zheng D, Liu G, et al. Preparation and characterization of galactosylated bovine serum albumin nanoparticles for liver-targeted delivery of oridonin. Int J Pharm. 2013; 448:79-86.

[54] Shen Z, Wei W, Tanaka H, Kohama K, Ma G, Dobashi T, et al. A galactosamine mediated drug delivery carrier for targeted liver cancer therapy. Pharmacol Res. 2011; 64:410-9.

[55] Bolanos K, Kogan MJ, Araya E. Capping gold nanoparticles with albumin to improve their biomedical properties. Int J Nanomedicine. 2019; 14:6387-406.

[56] Blaszkiewicz P, Kotkowiak M. Gold-based nanoparticles systems in phototherapy-current strategies. Curr Med Chem. 2018; 25:5914-29.

[57] Peralta DV, Heidari Z, Dash S, Tarr MA. Hybrid paclitaxel and gold nanorod-loaded human serum albumin nanoparticles for 
simultaneous chemotherapeutic and photothermal therapy on 4T1 breast cancer cells. ACS Appl Mater Interfaces. 2015; 7:7101-11.

[58] Lu H, Noorani L, Jiang Y, Du AW, Stenzel MH. Penetration and drug delivery of albumin nanoparticles into pancreatic multicellular tumor spheroids. J Mater Chem B. 2017; 5:9591-9.

[59] Ruan C, Liu L, Lu Y, Zhang Y, He X, Chen X, et al. Substance P-modified human serum albumin nanoparticles loaded with paclitaxel for targeted therapy of glioma. Acta Pharmaceutica Sinica B. 2017; 8:85-96.

[60] Nosrati H, Salehibar M, Manjili HK, Danafar H, Davaran S. Preparation of magnetic albumin nanoparticles via a simple and one-pot desolvation and co-precipitation method for medical and pharmaceutical application. Int J Biol Macromol. 2018; 108:909-15.

[61] Nosrati H, Sefidi N, Sharafi A, Danafar H, Manjili HK. Bovine serum albumin (BSA) coated iron oxide magnetic nanoparticles as biocompatible carriers for curcumin-anticancer drug. Bioorg Chem. 2018; 76:501-9.

[62] Delfiyal DSA, Thangavell K, Amirtham D. Preparation of curcumin loaded egg albumin nanoparticles using acetone and optimization of desolvation process. Protein J. 2016; 35:124-35.

[63] Prajapati A, Srivastava A. Characterization and encapsulation efficiency of egg albumin nanoparticles using EDC as crosslinker. J Sci Ind Res. 2019; 78:703-5.

[64] Olaitan V, Chaw CS. Desolvation conditions for production of sulfasalazine based albumin nanoparticles: physical properties. Pharm Front. 2019; 1:e190006. doi: 10.20900/pf20190006

[65] Salehiabar M, Nosrati H, Javani E, Aliakbarzadeh F, Manjili HK, Davaran S, Danafar H. Production of biological nanoparticles from bovine serum albumin as controlled release carrier for curcumin delivery. Int J Biol Macromol. 2018; 115:83-9.

[66] Kimura K, Yamasaki K, Nakamura H, Haratake M, Taguchi K, Otagiri M. Preparation and in vitro analysis of human serum albumin nanoparticles loaded with anthracycline derivatives. Chem Pharm Bull (Tokyo). 2018; 66:382-90.

[67] Fallacara AL, Mancini A, Zamperini C, Dreassi E, Marianelli S, Chiariello M, et al. Pyrazolo[3,4-d]pyrimidines-loaded human serum albumin (HSA) nanoparticles: preparation, characterization and cytotoxicity evaluation against neuroblastoma cell line. Bioorg Med Chem Lett. 2017; 27:3196-200.

[68] Gawde KA, Kesharwani P, Sau S, Sarkar FH, Padhye S, Kashaw SK, Iyer AK. Synthesis and characterization of folate decorated albumin bio-conjugate nanoparticles loaded with a synthetic curcumin difluorinated analogue. J Colloid Interface Sci. 2017; 496:290-9.

[69] Verma D, Gulati N, Kaul S, Mukherjee S, Nagaich U. Protein based nanostructures for drug delivery. J Pharm (Cairo). 2018; 2018:9285854. doi: 10.1155/2018/9285854

[70] Loureiro A, Azoiaa NG, Gomesb AC, Cavaco-Pauloa A. Albuminbased nanodevices as drug carriers. Curr Pharm Des. 2016; 22:1371-90.

[71] Tarhini M, Greige-Gerges H, Elaissari A. Protein-based nanoparticles: from preparation to encapsulation of active molecules. Int J Pharm. 2017; 522:172-97.

[72] Rai A, Jenifer J, Upputuri RTP. Nanoparticles in therapeutic applications and role of albumin and casein nanoparticles in cancer therapy. Asian Biomedicine. 2017; 11:3-20.

[73] Szczęch M, Szczepanowicz K. Polymeric core-shell nanoparticles prepared by spontaneous emulsification solvent evaporation and functionalized by the layer-by-layer method. Nanomaterials (Basel). 2020; 10:496. doi: 10.3390/nano10030496

[74] Lei Y, Cui F, Cun D, Tao A, Shi K, Lin W. Preparation, characterization and biodistribution of the lactone form of 10-hydroxycamptothecin (HCPT)-loaded bovine serum albumin (BSA) nanoparticles. Int J Pharm. 2007; 340:163-72.

[75] Guo H, Fei S, Zhang Y, Zhang Y, Gou J, Zhang L, et al. Teniposideloaded multilayer modified albumin nanoparticles with increased passive delivery to the lung. RSC Adv. 2016; 6:81110-19.

[76] Zhang JX, Zhu KJ. An improvement of double emulsion technique for preparing bovine serum albumin loaded PLGA microspheres. J Microencapsul. 2004; 21:775-85.

[77] Demirkurt B, Akdogan GC, Akdogan Y. Preparation of albumin nanoparticles in water-in-ionic liquid micro emulsion. J Mol Liq. 2019; 295:111713. doi: 10.1016/j.molliq.2019.111713

[78] Rani K. Preparation of BSANPs by using modified emulsodesolvation method. Eur J Pharm Med Res. 2016; 3:290-2.

[79] Maryam K, Shakeri S, Kiani K. Preparation and in vitro investigation of antigastric cancer activities of carvacrol-loaded human serum albumin nanoparticles. IET Nanobiotechnol. 2015; 9:294-9.

[80] Lu R, Li WW, Katzir A, Raichlin Y, Yu HQ, Mizaikoff B. Probing the secondary structure of bovine serum albumin during heat-induced denaturation using mid-infrared fiber optic sensors. Analyst. 2015; 140:765-70.

[81] Jana S, Maji N, Nayak AK, Sen KK, Basu SK. Development of chitosan-based nanoparticles through inter polymeric complexation for oral drug delivery. Carbohydr Polym. 2013; 98:870-6.

[82] Jana S, Mannaa S, Nayakb AK, Sena KK, Basua SK. Carbopol gel containing chitosan-egg albumin nanoparticles for transdermal aceclofenac delivery. Colloids Surf B Biointerfaces. 2014; 114:36-44.

[83] Papagiannopoulos A, Vlassi E. Stimuli-responsive nanoparticles by thermal treatment of bovine serum albumin inside its complexes with chondroitin sulfate. Food Hyd. 2019; 87:602-10.

[84] Thao LQ, Byeon HJ, Lee C, Lee S, Lee ES, Choi H-G, et al. Pharmaceutical potential of tacrolimus loaded albumin nanoparticles having targetability to rheumatoid arthritis tissues. Int J Pharm. 2016; 497:268-76.

[85] Yu X, Di Y, Xie C, Song Y, He H, Li H, et al. An in vitro and in vivo study of gemcitabine loaded albumin nanoparticles in a pancreatic cancer cell line. Int J Nanomedicine. 2015; 10:6825-34.

[86] Zhang Y, Yang Z, Tan X, Tang X, Yang Z. Development of a more efficient albumin-based delivery system for gambogic acid with low toxicity for lung cancer therapy. AAPS PharmSciTech. 2017; 18:1987-97.

[87] Thao LQ, Lee C, Kim B, Lee S, Kim TH, Kim JO, et al. Doxorubicin and paclitaxel co-bound lactosylated albumin nanoparticles having targetability to hepatocellular carcinoma. Colloids Surf B Biointerfaces. 2017; 152:183-91.

[88] Saha S, Kundu J, Verma RJ, Chowdhury PK. Albumin coated polymer nanoparticles loaded with plant extract derived quercetin for modulation of inflammation. Materialia. 2020; 9:100605. doi: 10.1016/j.mtla.2020.100605

[89] Li H, Zhao J, Wang A, Li Q, Cui W. Supramolecular assembly of protein-based nanoparticles based on tumor necrosis factor-related apoptosis-inducing ligand (TRAIL) for cancer therapy. Colloids Surf A Physicochem Eng Aspects. 2020; 590:124486. doi: 10.1016/j. colsurfa.2020.124486 


\section{A ASIAN

[90] Ding D, Tang X, Cao X, Wu J, Yuan A, Qiao Q, et al. Novel self-assembly endows human serum albumin nanoparticles with an enhanced antitumor efficacy. AAPS Pharm Sci Tech. 2014; 5:213-22.

[91] Wang S, Gong G, Su H, Liu W, Wang Z, Li L. Self-assembly of plasma protein through disulfide bond breaking and its use as a nanocarrier for lipophilic drugs. Polym Chem. 2014; 5:4871-4.

[92] Battogtokh G, Kang JH, Ko YT. Long-circulating self-assembled cholesteryl albumin nanoparticles enhance tumor accumulation of hydrophobic anticancer drug. Eur J Pharm Biopharm. 2015; 96:96-105.

[93] Xu L, He XY, Liu BY, Xu C, Ai SL, Zhuo RX, Cheng SX. Aptamer functionalized albumin based nanoparticles for targeted drug delivery. Colloids Surf B Biointerfaces. 2018; 1 71:24-30.

[94] Safavi MS, Shojaosadati SA, Yang HG, Kim Y, Park EJ, Lee KC, Na $\mathrm{DH}$. Reducing agent-free synthesis of curcumin-loaded albumin nanoparticles by self-assembly at room temperature. Int J Pharm. 2017; 529:303-9.
[95] Lee JE, Kim MG, Jang YL, Lee MS, Kim NW, Yin Y, et al. Self-assembled PEGylated albumin nanoparticles (SPAN) as a platform for cancer chemotherapy and imaging. Drug Deliv. 2018; 25:1570-8.

[96] Arpagaus C, Collenberg A, Rütti D, Assadpour E, Jafari SM. Nano spray drying for encapsulation of pharmaceuticals. Int J Pharm. 2018; 546:194-214.

[97] Arpagaus C. PLA/PLGA nanoparticles prepared by nano spray drying. J Pharm Invest. 2019; 49:405-26.

[98] Lee SH, Heng D, Ng WK, Chan HK, Tan RBH. Nano spray drying: a novel method for preparing protein nanoparticles for protein therapy. Int J Pharm. 2011; 403:192-200.

[99] Arpagaus C, John P, Collenberg A, Rütti D. Nanocapsules formation by nano spray drying. In: Jafari SM editor, Nanoencapsulation technologies for the food and nutraceutical industries. Cambridge, MA: Academic Press, 2017; p 346-401.

[100] Bürki K, Jeon I, Arpagaus C, Betz G. New insights into respirable protein powder preparation using a nano spray dryer. Inter J Pharm. 2011; 408:248-56. 